University of Nebraska - Lincoln DigitalCommons@University of Nebraska - Lincoln

Patrick Dussault Publications

Published Research - Department of Chemistry

2013

\title{
Tandem application of $\mathrm{C}-\mathrm{C}$ bond-forming reactions with reductive ozonolysis
}

\author{
Rachel Willand-Charnley \\ University of Nebraska-Lincoln \\ Patrick Dussault \\ University of Nebraska-Lincoln, pdussault1@unl.edu
}

Follow this and additional works at: http://digitalcommons.unl.edu/chemistrydussault

Willand-Charnley, Rachel and Dussault, Patrick, "Tandem application of C-C bond-forming reactions with reductive ozonolysis" (2013). Patrick Dussault Publications. 29.

http://digitalcommons.unl.edu/chemistrydussault/29

This Article is brought to you for free and open access by the Published Research - Department of Chemistry at DigitalCommons@University of Nebraska - Lincoln. It has been accepted for inclusion in Patrick Dussault Publications by an authorized administrator of DigitalCommons@University of Nebraska - Lincoln. 
Published in final edited form as:

J Org Chem. 2013 January 4; 78(1): 42-47. doi:10.1021/jo3015775.

Copyright $\odot 2012$ American Chemical Society

\title{
Tandem application of $\mathrm{C}-\mathrm{C}$ bond-forming reactions with reductive ozonolysis
}

\author{
Rachel Willand-Charnley and Patrick H. Dussault ${ }^{*}$ \\ Department of Chemistry, University of Nebraska-Lincoln, Lincoln, NE 68588-0304
}

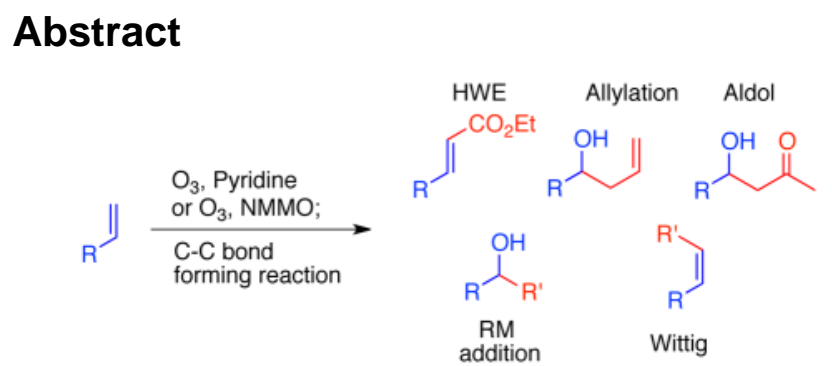

Several variants of reductive ozonolysis, defined here as the in situ generation of aldehydes or ketones during ozonolytic cleavage of alkenes, are demonstrated to work effectively in tandem with a number of $\mathrm{C}-\mathrm{C}$ bond-forming reactions. For reactions involving basic nucleophiles $(1,2-$ addition of Grignard reagents, Wittig or Horner-Emmons olefinations, and directed Aldol reactions of lithium enolates) the one-pot process offers a rapid and high-yielding alternative to traditional two-step protocols.

\section{INTRODUCTION}

Methods for generation of new carbon-carbon bonds from carbonyl electrophiles are among the most fundamental of synthetic transformations. The aldehyde and ketone starting materials are frequently generated via cleavage of alkenes with ozone. As a method for oxidative carbonyl generation, ozonolysis has many attractive features: compatibility with either protic or aprotic media, useful selectivity for cleavage of alkenes in the presence of other functional groups, the need for only oxygen and electricity as inputs, and the absence of metal-containing byproducts. ${ }^{1}$ However, on the negative side, the intermediate ozonides or hydroperoxyacetals are often capable of dangerously exothermic self-accelerating decomposition reactions. ${ }^{2}$ The potential hazards related to accumulation of energetic intermediates have limited large-scale application of ozonolysis, ${ }^{3}$ and motivated the development of flow-based or modular reactor systems. ${ }^{4}$ We have recently reported several methods for "reductive" ozonolysis that directly generate carbonyl products, avoiding formation of isolable peroxides. ${ }^{5 \mathrm{a}-\mathrm{c}}$ We now report the successful application of reductive ozonolyses in tandem with a number of the most common methods for carbon-carbon bondforming reactions.

To understand the potential value of one-pot application of reductive ozonolysis and C-C bond-forming reactions, it is useful to look at a traditional ozonolysis pathway (Scheme 1). ${ }^{1 \mathrm{a}, 6}$ Cycloaddition of an alkene with ozone generates a 1,2,3-trioxolane, or "primary

corresponding author: pdussault1@unl.edu.

Supporting Information: ${ }^{1} \mathrm{H}$ NMR of known molecules prepared as described above and characterization $\left({ }^{1} \mathrm{H},{ }^{13} \mathrm{C}\right.$, IR and HRMS) for ethyl 11-acetoxy-2-undecenoate is available free of charge via the Internet at http://pubs.acs.org. 
ozonide, ${ }^{7}$ which undergoes cycloreversion even at low temperatures to generate a carbonyl and a short-lived carbonyl $O$-oxide. ${ }^{6,8}$ Reaction in aprotic media favors cycloaddition with a dipolarophile, frequently the cogenerated aldehyde, to furnish 1,2,4-trioxolanes (ozonides). ${ }^{9}$ Alternatively, nucleophilic trapping by unhindered alcohols generates hydroperoxyacetals. ${ }^{10,11}$ Ozonides and hydroperoxyacetals are most often decomposed to aldehydes or ketones by reduction, ${ }^{12}$ although alternative workups are known based upon base-promoted fragmentations. ${ }^{13}$ Reduction can be accomplished with many reagents, but three are used most frequently. ${ }^{1 \mathrm{a}, 12} \mathrm{Me}_{2} \mathrm{~S}$ is a mild and chemoselective reagent which can be used in excess, and generates DMSO as a byproduct. However, as became obvious in the course of this work, the reaction of $\mathrm{Me}_{2} \mathrm{~S}$ with ozonides is often so slow, so slow in the case of hindered ozonides as to result in potentially hazardous situations. ${ }^{14} \mathrm{Zn} / \mathrm{HOAc}$ rapidly reduces most peroxides but the acidic conditions are incompatible with many substrates. $\mathrm{Ph}_{3} \mathrm{P}$ reduces all hydroperoxyacetals and most ozonides, but the formation of stoichiometric phosphine oxide can complicate product isolation. ${ }^{15}$

\section{Reductive ozonolysis}

We have recently described three protocols for reductive ozonolysis. The first (Scheme 2, path a) involves an operationally simple protocol, ozonolysis in wet acetonitrile or wet acetone.${ }^{5 \mathrm{~b}}$ In this case, attack of solubilized water on the carbonyl oxide generates a tetrahedral intermediate that decomposes to furnish the carbonyl product(s) and hydrogen peroxide. The second (Scheme 2, path b) involves ozonolysis in the presence of $N$-methyl morpholine $N$-oxide (NMMO) or related $N$-oxides. ${ }^{5 a}$ Nucleophilic trapping of the carbonyl oxide generates unstable zwitterionic acetals, which fragment to generate the target carbonyl, $\mathrm{O}_{2}$, and a molecule of amine. ${ }^{16}$ Finally, we recently described a general and high yielding protocol for direct conversion of alkenes to aldehydes and ketones based upon ozonolysis in the presence of added pyridine. ${ }^{5 \mathrm{c}}$ This transformation (Scheme 2, path c) appears to involve an unprecedented pyridine-promoted dimerization and fragmentation of carbonyl oxides. Of particular relevance to the current studies, the $\mathrm{N}$-oxide and pyridinepromoted protocols are conducted under anhydrous conditions and generate byproducts (amines, $N$-oxides, or pyridine) not expected to interfere with transformations based upon carbon nucleophiles.

\section{RESULTS}

We investigated in situ ozonolytic generation of aldehydes and ketones in conjunction with several widely used methods for carbon-carbon bond formation: 1,2-organometallic additions, Wittig and Horner-Emmons olefinations, Aldol reactions, and allylations. Because the majority of these transformations involve the use of water-sensitive reagents, we focused our efforts on the reductive protocols based upon $\mathrm{N}$-oxides (Scheme $2 \mathrm{~b}$ ) and pyridine (Scheme 2c).

\section{Horner-Emmons olefinations}

As illustrated in Table 1, addition of lithiated triethyl phosphonoacetate to the crude reaction mixtures resulting from reductive ozonolysis provided very good yields of $a, \beta$-unsaturated esters. Similar yields were available through a traditional multistep route involving $\mathrm{Me}_{2} \mathrm{~S}$ (3-5 equiv) reduction of the intermediate ozonide (not shown); however, the reduction step required up to $24 \mathrm{~h}$ for removal of ozonide.

\section{Wittig olefination}

Wittig olefination with nonstabilized ylides also paired effectively with reductive ozonolysis (Table 2). In the case of the $N$-oxide protocol, we found it most effective to conduct the subsequent Wittig reaction at $0{ }^{\circ} \mathrm{C}$ or above to avoid precipitation of reagents. 


\section{Organometallic addition}

Direct addition of organometallics to solutions of ozonolysis-derived aldehydes was investigated with Grignard reagents (Table 3). Good yields of secondary or tertiary alcohols were obtained using only a slight excess (1.1 equiv) of the alkyl or aryl magnesium reagent.

\section{Aldol reactions}

Addition of the lithium enolate of cyclohexanone to the crude reaction mixtures resulting from the pyridine- or NMMO-promoted reductive ozonolyses furnished good yields of 3hydroxyketones as $~ 3: 1$ mixtures of antilsyn diastereomers (Table 4). The yields and sense of stereoselection were very similar to results previously reported for analogous reactions of isolated aldehydes (see experimental section). In contrast, attempts to perform the corresponding Lewis acid-catalyzed Mukaiyama aldol reactions with a trimethylsilyl enol ether were unsuccessful; in fact, addition of enol ethers and $\mathrm{TiCl}_{4}$ to pyridine-containing solutions resulted in the formation of a viscous, dark material.

\section{Allylations}

Lewis acid-catalyzed allylations were investigated in tandem with both the $\mathrm{N}$-oxide and the pyridine protocols (Table 5). ${ }^{17}$ Treatment of the products of either protocol with allylsilane and $\mathrm{BF}_{3} \cdot \mathrm{OEt}_{2}$ (excess) furnished homoallyl alcohols in good yield. In contrast, $\mathrm{TiCl}_{4}$ promoted allylation was unsuccessful when applied in tandem with pyridine-promoted reductive ozonolysis and could be applied in tandem with the NMMO protocol only if Lewis acid was used in excess relative to the $\mathrm{N}$-oxide. Attempted allylations in the presence of more oxophilic Lewis acids such as $\mathrm{Yb}(\mathrm{OTf})_{3}$ and TMSOTf were unsuccessful.

\section{DISCUSSION}

Ozonolysis has been previously investigated as a one-pot reaction in tandem with a number of reductive transformations, including borohydride reduction, ${ }^{18}$ reductive amination, ${ }^{19}$ hydrogenation, ${ }^{20}$ and Clemmensen reduction. ${ }^{21}$ Oxidation of ozonolysis products with $\mathrm{H}_{2} \mathrm{O}_{2}$ has been employed for the synthesis of carboxylic acids, ${ }^{22,23}$ and chromic acid oxidation has been used to digest ozonides. ${ }^{24}$

However, the record related to $\mathrm{C}-\mathrm{C}$ bond formation is much thinner. Building upon an efficient synthesis of aldehydes via base-promoted fragmentation of terminal ozonides, ${ }^{13}$ Hon's lab demonstrated the ability to convert the same ozonides directly to unsaturated esters upon reaction with stabilized Wittig ylides. ${ }^{25}$ The combination of $\mathrm{SnCl}_{2}$ and ethyl diazoacetate has been shown to achieve the direct conversion of ozonolysis-derived peroxides to 3-ketoesters. ${ }^{26}$ Cyclic oxonitriles have been prepared by pairing the ozonolysis of unsaturated nitriles with a subsequent intramolecular aldol reaction. ${ }^{27}$ Ozonides are also known to react directly with organometallic reagents. ${ }^{28}$ However, this methodology requires handling of a peroxide intermediate and the use of excess organometallic (to cleave the O-O bond and then react with the liberated carbonyl). ${ }^{29}$

Reductive ozonolyses, which achieve the direct conversion of alkenes to ketones or aldehydes, were anticipated to partner well with methods for carbon-carbon bond formation. In particular, the pyridine or amine $N$-oxide promoters were not expected to interfere with reactions involving basic nucleophiles. This assumption was supported by our results, which found no significant change in stoichiometry or yield relative to a traditional two-step procedure for reactions with phosphonate anions, Wittig ylides, Grignard reagents, or lithium enolates. Curiously, although the ozonolysis of terminal alkenes generates formaldehyde as a byproduct, ${ }^{1 \mathrm{a}, 6,8}$ we did not observe products of one-carbon homologation, even in the presence of $\mathrm{PhMgBr}$, a reagent for which the derived alcohol 
would have been easily observed and isolated. The failure to trap formaldehyde, which is a definite plus in terms of avoiding unnecessary consumption of reagent, presumably reflects loss of this highly volatile byproduct under reaction conditions. In contrast, application of a one-pot ozonolysis/Horner-Emmons protocol to a cyclic alkene furnished a good yield of the product derived from a ketoaldehyde (eq 1).

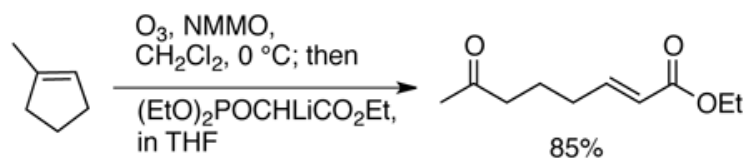

In contrast, Mukaiyama aldol reactions failed completely under the tandem conditions, while Hosomi-Sakurai allylations were successful only in the presence of a significant excess of Lewis acid. These results are not completely surprising; pyridine and NMMO are strong Lewis bases, and we found no examples of previous pairings of ozonolysis with Lewis-acid promoted allylation chemistry. ${ }^{30}$ Based upon our results, we cannot recommend the tandem application of reductive ozonolysis in sequences employing strong Lewis acids.

Although we did not explore enamine-based aldol or Michael chemistry, the conditions of the pyridine-mediated reductive ozonolyses are likely to pair well with these increasingly popular approaches for carbon-carbon bond formation.

A comparison with traditional methodology reveals practical advantages of the new approach. For while application of an traditional ozonolysis/Horner-Emmons reaction sequence (ozonolysis; $\mathrm{Me}_{2} \mathrm{~S}$ reduction; Horner-Emmons olefination) to 3-butenylbenzene (eq 2) furnishes ethyl 5-phenyl-2-pentenoate in a yield only slightly lower than for the onepot approach (see Table 1), but requires $24 \mathrm{~h}$ or more for complete consumption of the ozonide by $\mathrm{Me}_{2} \mathrm{~S}$ (6-8 equiv) compared with minutes in the one-pot procedures.

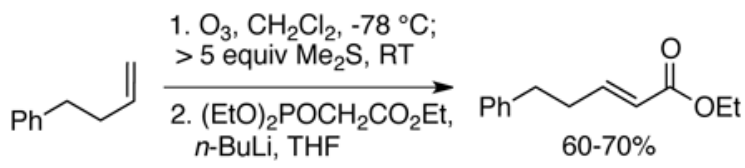

In conclusion, the application of convenient and high-yielding approaches for reductive ozonolysis in tandem with a number of widely used methods for $\mathrm{C}-\mathrm{C}$ bond-forming reactions is shown to result in streamlined synthetic sequences. It is hoped that the methodology will be as widely applied as an analogous strategy partnering C-C bondforming reactions with Swern oxidations. ${ }^{31}$

\section{Notes on Safety}

Although the procedures described above typically preclude formation of significant amounts of ozonides and other peroxides, experimenters are urged to verify the absence of significant amounts of peroxides before concentrating crude reaction mixtures. ${ }^{32}$ Ozonolyses should always be conducted with an awareness of the potential for spontaneous and exothermic decompositions. ${ }^{2}$ 


\section{Experimental Section}

All reagents and solvents were used as supplied commercially, except $\mathrm{CH}_{2} \mathrm{Cl}_{2}$ (distilled from $\mathrm{CaH}_{2}$ ), THF (distilled from Na/benzophenone) and pyridine (stored over activated $4 \AA$ sieves). All reactions were conducted under an atmosphere of $\mathrm{N}_{2}$ except where noted. NMR spectra were acquired in $\mathrm{CDCl}_{3}$; chemical shifts are reported in ppm referenced to the solvent peaks of $\mathrm{CDCl}_{3}\left(7.26 \mathrm{ppm}\right.$ for ${ }^{1} \mathrm{H}$ and $77.1( \pm 0.1) \mathrm{ppm}$ for $\left.{ }^{13} \mathrm{C}\right)$. The sample was analyzed by GC/MS (30 m DB-5MS column with a 1:200 injector split and $1 \mathrm{~mL} / \mathrm{min}$ flow of $\mathrm{He}_{2}$ gas, analysis on an ion trap scanning in EI mode over 50-650 m/z range, with the ion source set at $200^{\circ} \mathrm{C}$ ). IR was acquired via ATR as neat films on a ZrSe crystal with selected absorbances reported in $\mathrm{cm}^{-1}$. Silica gel was used for flash column chromatography. Thin layer chromatography (TLC) was performed on $0.25 \mathrm{~mm}$ hard-layer silica $\mathrm{G}$ plates containing a fluorescent indicator. Developed TLC plates were visualized with a hand-held UV lamp or by charring after staining with $1 \%$ ceric sulfate/10\% ammonium molybdate in $10 \% \mathrm{H}_{2} \mathrm{SO}_{4}$.

\section{Reductive ozonolysis in the presence of pyridine}

The alkene (internal or terminal) substrate $(1-3 \mathrm{mmol})$ and dry pyridine ( $3-9 \mathrm{mmol})$ were dissolved in dry $\mathrm{CH}_{2} \mathrm{Cl}_{2}(15-20 \mathrm{~mL})$ in a flame-dried flask under $\mathrm{N}_{2}$. The solution was cooled to $-78{ }^{\circ} \mathrm{C}$, at which point a stream of $\mathrm{O}_{3} / \mathrm{O}_{2}$ (delivering $\sim 1 \mathrm{mmol} / \mathrm{min}$ of $\mathrm{O}_{3}$ ) was introduced through a disposable pipet for a period proportional to the amount of alkene. Once consumption of alkene was complete, the reaction was sparged with $\mathrm{O}_{2}$ and then $\mathrm{N}_{2}$. The resulting solution was added dropwise (syringe or cannula) to the next reaction mixture.

\section{Reductive ozonolysis in the presence of $\mathbf{N}$-methyl morpholine $\mathbf{N}$-oxide (NMMO)}

The alkene (internal or terminal) substrate (1-3 mmol) and NMMO (3-5 equiv relative to alkene) were dissolved in dry $\mathrm{CH}_{2} \mathrm{Cl}_{2}(15-20 \mathrm{~mL})$ in a flame-dried flask under $\mathrm{N}_{2}$. The solution was cooled to $0{ }^{\circ} \mathrm{C}$, after which ozonolysis carried out as described in the previous procedure, as was application of the reaction mixture to the following reaction.

\section{Tandem application of reductive ozonolysis and Horner-Emmons olefination}

To a $-78{ }^{\circ} \mathrm{C}$ solution of triethyl phosphonoacetate $(4 \mathrm{mmol})$ in THF $(20 \mathrm{~mL})$ was dropwise added $n$-butyl lithium ( $5 \mathrm{mmol}$, as a nominally $2.3 \mathrm{M}$ solution in hexane). The reaction was allowed to stir for an hour, whereupon the $\mathrm{CH}_{2} \mathrm{Cl}_{2}$ solution of the carbonyl product of ozonolysis (nominally $3 \mathrm{mmol}$ based upon alkene starting material) was added dropwise. The reaction mixture was then allowed to warm to room temperature and stirred for an additional $2.5 \mathrm{~h}$. The reaction was quenched with saturated $\mathrm{NH}_{4} \mathrm{Cl}(4 \mathrm{~mL})$ and the mixture extracted with $30 \mathrm{~mL}$ ether $(3 \mathrm{x})$. The combined organic layers were washed with brine and extracted. The aqueous washes were back extracted with a small amount of ether $(3 \mathrm{x})$ the combined organic layers were dried with sodium sulfate and the residue obtained upon concentration was purified via flash chromatography with EA/Hex to furnish the desired product.

\section{Tandem application of reductive ozonolysis and Grignard reactions}

To a solution of $\mathrm{CH}_{2} \mathrm{Cl}_{2}$ and carbonyl product (nominally $3 \mathrm{mmol}$ ), prepared from an alkene via ozonolysis as already discussed $\mathrm{d}^{5 \mathrm{a}, \mathrm{c}}$ was recooled to $0{ }^{\circ} \mathrm{C}$, whereupon a stoichiometric amount of phenyl or methyl magnesium bromide ( $3 \mathrm{mmol}, 1$ equiv, nominally $1 \mathrm{M}$ in THF) was added. The reaction was monitored by TLC and, when complete, was quenched by dropwise addition of water followed by a few drops of $6 \mathrm{Maq}$. HCl. The mixture was diluted with a volume of saturated aq. $\mathrm{NH}_{4} \mathrm{Cl}$ and the separated aqueous layer was extracted thrice 
with $\mathrm{CH}_{2} \mathrm{Cl}_{2}$. The remainder of the work-up was performed as for the Horner-Emmons sequence described above.

\section{Tandem application of reductive ozonolysis and allylation reactions}

To a room temperature $\mathrm{CH}_{2} \mathrm{Cl}_{2}$ solution of the carbonyl product (nominally $3 \mathrm{mmol}$ ), prepared from an alkene via ozonolysis as already discussed, ${ }^{5 \mathrm{a}, \mathrm{c}}$ was dropwise added $\mathrm{TiCl}_{4}$ (6 mmol, neat). After approximately ten minutes, allyltrimethylsilane $(2 \mathrm{mmol})$ was added dropwise and the reaction mixture was allowed to stir for 45 minutes. The reaction was quenched with deionized water. The organic layer was extracted with $30 \mathrm{~mL}$ ether $(3 \mathrm{x})$. The combined organic layers were dried and concentrated as described previously followed by drying, concentration, and purification by procedures similar to those described above.

\section{Tandem application of reductive ozonolysis and Wittig olefination}

A $\mathrm{CH}_{2} \mathrm{Cl}_{2}$ solution of carbonyl product (nominally $3 \mathrm{mmol}$ ) was prepared from an alkene via ozonolysis as discussed above. ${ }^{5 \mathrm{a}, \mathrm{c}}$ A stoichiometric $(3 \mathrm{mmol}$; 1 equiv relative to nominal amount of carbonyl) amount of pentyltriphenylphosphonium bromide was placed in a flamedried $50 \mathrm{~mL}$ RBF capped with a septa. The atmosphere was removed under vacuum and backfilled with $\mathrm{N}_{2}$. The salt was dissolved in THF (10-15 mL) and the solution cooled to 0 ${ }^{\circ} \mathrm{C}$. The mixture was allowed to stir for ten minutes, whereupon a solution of $n$-BuLi (3 mmol, nominally $2.3 \mathrm{M}$ in Hex) was added drop wise. The reaction was allowed to stir for $0.5 \mathrm{~h}$, after which the solution of aldehyde was added dropwise. The reaction, when complete $(\sim 0.5-1 \mathrm{~h}$, TLC) was quenched by dropwise addition of water and the resulting mixture extracted with $30 \mathrm{~mL}$ of ether. The organic layer was washed successively with aqueous sodium bicarbonate, water and bleach. The aqueous washes were back extracted three times with a small amount of ether. The combined organic layers were dried and concentrated as described previously followed by drying, concentration, and purification by procedures similar to those described above.

\section{Tandem application of reductive ozonolysis with Aldol reactions}

The carbonyl product (nominally $3 \mathrm{mmol}$ ) was prepared from an alkene via ozonolysis as already discussed. ${ }^{5 \mathrm{a}, \mathrm{c}}$ To a stirring $0{ }^{\circ} \mathrm{C}$ solution of diisopropylamine $(3 \mathrm{mmol})$ in $7 \mathrm{~mL}$ THF in a flame-dried RBF was added n-butyl lithium ( $3 \mathrm{mmol}$, as a nominally $2.3 \mathrm{M}$ solution in hexane). After 15 minutes, a solution of cyclohexanone ( $3 \mathrm{mmol})$ in THF ( $2 \mathrm{~mL})$ was added. The reaction was cooled to $-78{ }^{\circ} \mathrm{C}$ and the $\mathrm{CH}_{2} \mathrm{Cl}_{2}$ solution of the aldehyde product was added. After 15 minutes the aldehyde was completely consumed (TLC) and the reaction was quenched with $1 \mathrm{M} \mathrm{HCl}$ (1-2 equiv). The solution (emulsion) was extracted with $30 \mathrm{~mL}$ ether and the organic layer was washed successively with aqueous sodium bicarbonate, water and aqueous sodium chloride. The aqueous washes were back extracted with a small amount of ether $(3 \mathrm{x})$. The combined organic layers were dried and concentrated as described previously followed by drying, concentration, and purification by procedures similar to those described above. The syn/anti ratios ( 1:3 in all cases) were assigned by comparison of the ${ }^{1} \mathrm{H}$ NMR spectra with literature reports. ${ }^{33-37}$

\section{Products prepared via tandem ozonolysis}

The following were prepared according to the experimental procedures described. All compounds afforded spectral data identical to values described in the literature.

(E)-Ethyl 11-acetoxyundec-2-enoate (via Horner-Emmons): colorless oil; $\mathrm{R}_{f}=0.5$ (10\% EA/hex); ${ }^{1} \mathrm{H}\left(400 \mathrm{MHz}, \mathrm{CDCl}_{3}\right) \delta 6.98(1 \mathrm{H}, \mathrm{dt}, 7.0,15.7), 5.82(1 \mathrm{H}, \mathrm{dt}, 1.5$, 15.6), $4.21(2 \mathrm{H}, \mathrm{q}, 7.1), 4.07(2 \mathrm{H}, \mathrm{t}, 6.7), 2.19(2 \mathrm{H}, \mathrm{dq}, \sim 1,6.7), 2.06(3 \mathrm{H}, \mathrm{s}), 1.63(2 \mathrm{H}$, p, 6.7), $1.47(2 \mathrm{H}, \mathrm{p}, 6.9), 1.30(11 \mathrm{H}, \mathrm{t}, 7.1) ;{ }^{13} \mathrm{C}\left(100.6 \mathrm{MHz}, \mathrm{CDCl}_{3}\right) \delta 171.4,166.8$, 149.4, 121.3, 64.6, 60.1, 32.2, 29.2, 29.1, 29.0, 28.6, 28.0, 25.9, 21.0, 14.3; IR 2929, 
2856, $1717 \mathrm{~cm}^{-1}$; HRMS (ESI, $\left.\mathrm{MeOH} / \mathrm{H}_{2} \mathrm{O}, \mathrm{NaOAc}\right)$, calc. for $\mathrm{C}_{15} \mathrm{H}_{26} \mathrm{NaO}_{4}(\mathrm{M}+\mathrm{Na})^{+}$: 293.1729; found 293.1722 (-2.0 ppm).

(E)-ethyl 5-phenylpent-2-enoate (via Horner-Emmons): $\mathrm{Rf}=0.7$ in $(10 \% \mathrm{EA} / \mathrm{hex}){ }^{38}$

$(\boldsymbol{E})$-Ethyl 4-acetoxybut-2-enoate (via Horner-Emmons): $\mathrm{R}_{f}=0.4$ in (10\% EA/hex). ${ }^{39}$

(E)-Ethyl 7-oxooct-2-enoate (via Horner-Emmons): $\mathrm{R}_{f}=0.7$ in (10\% EA/hex). ${ }^{40}$

(Z)-Tridec-5-ene (via Wittig): $\mathrm{R}_{f}=0.92(10 \% \mathrm{EA} / \mathrm{hex}){ }^{41}$

(Z)-Tetradec-5-ene (via Wittig): $\mathbf{R}_{f}=0.70$ (10\% EA/hex) ${ }^{41}$

(Z)-Oct-3-en-1-ylbenzene (via Wittig): $\mathrm{R}_{f}=0.75$ (10\% EA/hex). ${ }^{42}$

2-(1-Hydroxy-3-phenylpropyl)cyclohexanone (via Aldol): $\mathrm{R}_{f}=0.22$ (10\% EA/hex), isolated as an approximately 3:1 mixture of anti and $s y n$ isomers, determined by comparison on NMR spectra with literature reports. The stereochemical outcome is very similar to that reported for corresponding reactions of 3-phenylpropanal. ${ }^{33}$

2-(1-Hydroxynonyl)cyclohexanone (via Aldol): $\mathrm{R}_{f}=0.38$ (10\% EA/hex), isolated as an approximately 3:1 mixture of anti and syn isomers, determined by comparison on NMR spectra against literature reports. The stereochemical outcome is very similar to that reported for corresponding reactions of analogous aldehydes. ${ }^{34}$

2-(1-Hydroxyoctyl)cyclohexanone (via Aldol): $\mathrm{R}_{f}=0.40(10 \% \mathrm{EA} / \mathrm{hex})^{35}$

Decan-2-ol (via Grignard): $\mathrm{R}_{f}=0.20(10 \% \mathrm{EA} / \mathrm{hex}){ }^{43}$

1-Phenyldecan-1-ol (via Grignard): $\mathrm{R}_{f}=0.26$ in (10\% EA/hex). ${ }^{44}$

2-Phenylnopinol (via Grignard): $\mathrm{R}_{f}=0.20(10 \% \mathrm{EA} / \mathrm{hex}) .{ }^{45}$

4-(tert-Butyl)-1-methylcyclohexanol (via Grignard): $\mathrm{R}_{f}=0.20$ (10\% EA/hex) ${ }^{46}$

1,3-Diphenylpropan-1-ol (via Grignard): $\mathrm{R}_{f}=0.22$ (10\% EA/hex). ${ }^{47}$

1-Phenyloctan-1-ol (via Grignard): $\mathrm{R}_{f}=0.33$ (10\% EA/hex). ${ }^{46}$

1-Phenylhex-5-en-3-ol (via allylation): $\mathrm{R}_{f}=0.8(10 \% \mathrm{EA} / \mathrm{hex}){ }^{48}$

Dodec-1-en-4-ol (via allylation): $\mathrm{R}_{f}=0.36(10 \% \mathrm{EA} / \mathrm{hex}) .{ }^{49}$

Undec-1-en-4-ol (via allylation): $\mathrm{R}_{f}=0.34$ (10\% EA/hex). ${ }^{50}$

\section{Supplementary Material}

Refer to Web version on PubMed Central for supplementary material.

\section{Acknowledgments}

Research was conducted with funding from the NSF (CHE-1057982) in facilities remodeled with support from the NIH (RR016544).

\section{References}

1. Bailey PS. Ozonation in Organic Chemistry. Olefinic Compounds. 1For more recent overviews of ozonolysis, see: McGuire J, Bond G, Haslam PJ. Handbook of Chiral Chemicals (2). 2006Taylor \& FrancisBoca Raton:165.Van Ornum SG, Champeau RM, Pariza R. Chem Rev. 2006; 106:2990. [PubMed: 16836306] East M. Chemistry Today (Chimica Oggi). 2006; 24:46.

2. See, for example: Kula J. Chem Health Saf. 1999; 6:21.Zabicky J. Rappoport Z. The Chemistry of the Peroxide Group. 2John Wiley \& SonsChichester2006; (pt 2):597.Ragan JA, am Ende DJ, Brenek SJ, Eisenbeis SA, Singer RA, Tickner DL, Teixeira JJ, Vanderplas BC, Weston N. Org Proc 
Res Dev. 2003; 7:155.Hida T, Kikuchi J, Kakinuma M, Nogusa H. Org Proc Res Dev. 2010; 14:1485.

3. For a description of an ozonolysis reactor designed to achieve formation and decomposition of ozonides, see: http://www.thalesnano.com/products/o-cube.

4. For an example of a flow-based process, see: O'Brien M, Baxendale IR, Ley SV. Org Lett. 2010; 12:1596. [PubMed: 20218640]

5. a. Willand-Charnley R, Fisher T, Johnson B, Dussault PH. Org Lett. 2012; 14:2242. [PubMed: 22512349] b Schiaffo CE, Dussault PH. J Org Chem. 2008; 73:4688. [PubMed: 18505290] c Schwartz C, Raible J, Mott K, Dussault PH. Tetrahedron. 2006; 62:10747.

6. Criegee R. Angew Chem Int Ed Engl. 1975; 14:745.

7. Although primary ozonide and molozonide are often used interchangeably in older literature, the latter term is now predominantly used to describe alternate structures.

8. Bunnelle WH. Chem Rev. 1991; 91:335.

9. Kuczkowski RL. Chem Soc Rev. 1992; $21: 79$.

10. Yamamoto Y, Niki E, Kamiya Y. Bull Chem Soc Jpn. 1982; 55:2677.

11. Steinfeldt N, Bentrup U, Jaehnisch K. Ind Eng Chem Res. 2010; 49:72.

12. Kropf, H. Houben-Weyl Methoden Der Organische Chemie. Kropf, H., editor. Vol. E13/2. Georg Thieme; Stuttgart, Germany: 1988. p. 1111

13. Hon YS, Lin SW, Chen YJ. Synth Comm. 1993; 23:1543-53.Hon YS, Lin SW, Ling L, Chen YJ. Tetrahedron. 1995; 51:5019.For the direct conversion of terminal alkenes to methyl esters in basic methanol, see Marshall JA, Garofalo AW. J Org Chem. 1993; 58:3675.

14. See, for example, Chen L, Wiemer DF. J Org Chem. 2002; 67:7561. [PubMed: 12375999]

15. See, for example: Årstad E, Barrett AGM, Hopkins BT, Koebberling J. Org Lett. 2002; 4:1975. [PubMed: 12027661]

16. For a theoretical exploration of the N-oxide fragmentation, see: Hang J, Ghorai P, FinkenstaedtQuinn SA, Findik I, Sliz E, Kuwata KT, Dussault PH*. J Org Chem. 2012; 77:1233. [PubMed: 22283731]

17. Fleming I, Dunogues J, Smithers R. Org React. 1989; 37:57.

18. Chandrasekhar S, Shyamsunder T, Prakash SJ, Prabhakar A, Jagadeesh B. Tetrahedron Letters. 2006; 47:47.

19. Kyasa SK, Fisher TJ, Dussault PH. Synthesis. 2011:3475.

20. For leading references, see ref. 1a and Pryde EH, Anders DE, Teeter HM, Cowan JC. J Org Chem. 1962; 27:3055.for sequential application of ozonolysis and hydrogenation within modular units, see reference 3.

21. Xu S, Toyama T, Nakamura J, Arimoto H. Tetrahedron Lett. 2010; 51:4534.

22. Biellmann JF, Rodriguez GH. J Org Chem. 1996; 61:1822. [PubMed: 11667055]

23. Bailey PS. J Org Chem. 1957; 22:1548.

24. Leuser H, Perrone S, Liron F, Kneisel FF, Knochel P. Angew Chem Int Ed. 2005; 44:4627-31.

25. Hon YS, Lu L, Chang RC, Lin SW, Sun PP, Lee CL. Tetrahedron. 2000; 56:9269.

26. Holmquist CR, Roskamp EJ. Tetrahedron Lett. 1990; 31:4991.

27. Fleming FF, Huang A, Sharief VA, Pu Y. J Org Chem. 1997; 62:3036. [PubMed: 11671680]

28. Sparks, JW.; Knobloch, JO. U. S. Patent No 2671812. 1954. Chem Abs. 1955:28287.Greenwood FL, Haske BJ. J Org Chem. 1965; 30:1276.

29. Paquette has reported that reaction of ozonides with $\mathrm{Zn}$ in the presence of allyl bromides results in both reduction and allylation: Schloss JD, Paquette LA. Synth Commun. 1998; 28:2887.

30. The Lewis acid promoted allylation of ozonides and related peroxides has been investigated: Dussault PH, Lee H-J, Liu X. J Chem Soc, Perkin Trans. 2000:3006.

31. Ireland RE, Norbeck DW. J Org Chem. 1985; 50:2198.

32. Smith LL, Hill FL. J Chrom. 1972; 66:101.

33. Yanagisawa A, Matsumoto Y, Asakawa K, Yamamoto H. Tetrahedron. 2002; 58:8331.

34. Spreitzer H, Anderwald C, Buchbauer G. Flavour and Fragrance Journal. 1995; 10:287.

J Org Chem. Author manuscript; available in PMC 2014 January 04. 
35. Findlay JA, Desai DN, Macaulay JB. Can J Chem. 1981; 59:3303.

36. Denmark SE, Wong KT, Stavenger RA. J Am Chem Soc. 1997; 119:2333.

37. Estevez RE, Paradas M, Millan A, Jimenez T, Robles R, Cuerva JM, Oltra JE. J Org Chem. 2009; 73:1616. [PubMed: 18189411]

38. Claridge TDW, Davies SG, Lee JA, Nicholson RL, Roberts PM, Russell AJ, Smith AD, Toms SM. Org Lett. 2008; 10:5437. [PubMed: 18975957]

39. Yamane T, Kikukawa K, Takagi M, Matsuda T. Tetrahedron. 1973; 29:955.

40. Lory PMJ, Jones RCF, Iley JN, Coles SJ, Hursthouse MB. Org Biomol Chem. 2006; 4:3155. [PubMed: 16886085]

41. Cahiez G, Avedissian H. Synthesis. 1998:1199.

42. Harada T, Katsuhira T, Hara D, Kotani Y, Maejima K, Kaji R, Oku A. J Org Chem. 1993; 58:4897.

43. Nakamura K, Matsuda T. J Org Chem. 1998; 63:8957.

44. Kose O, Saito S. Org Biomol Chem. 2010; 8:896. [PubMed: 20135049]

45. Brown HC, Weissman SA, Perumal PT, Dhokte UP. J Org Chem. 1990; 55:1217.

46. Bouffard J, Itami K. Org Lett. 2009; 11:4410. [PubMed: 19708680]

47. Liao S, Yu K, Li Q, Tian H, Zhang Z, Yu X, Xu Q. Org Biomol Chem. 2012; 10:2973. [PubMed: 22261789]

48. Wang T, Hao XQ, Zhang XX, Gong JF, Song MP. Dalton Trans. 2011; 40:8964. [PubMed: 21655570]

49. Lin MH, Lun LZ, Chuang TH, Liu HJ. Tetrahedron. 2012; 68:2630.

50. Bhuyan BK, Borah AJ, Senapati KK, Phukan P. Tetrahedron Lett. 2011; 52:2649-2651. 


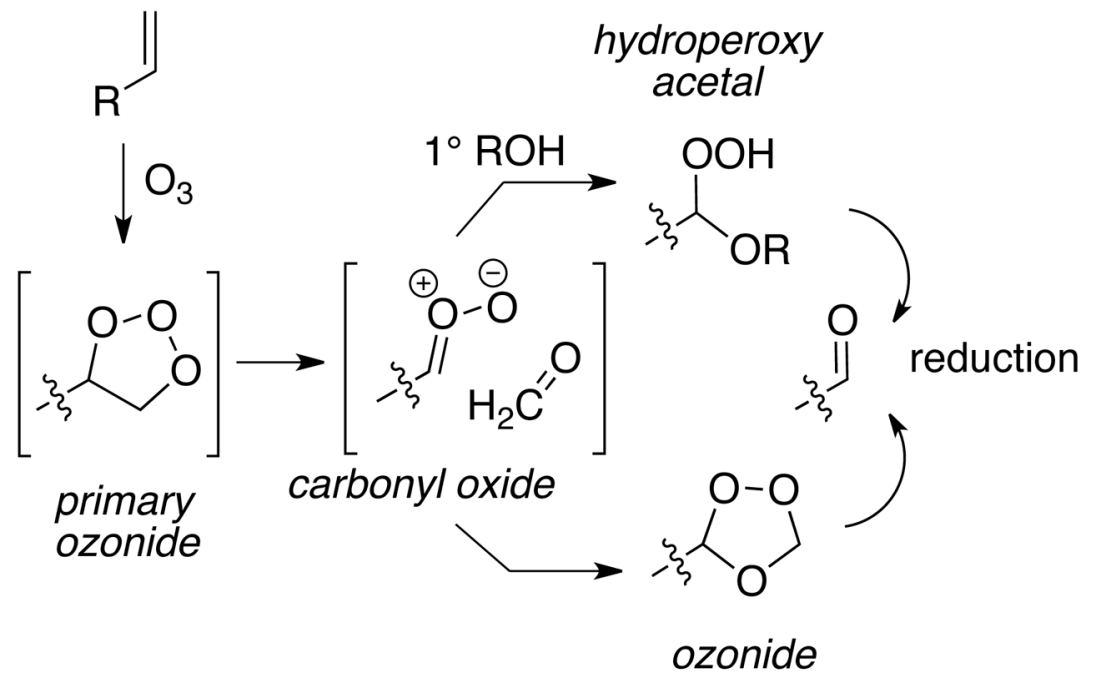

Scheme 1.

Overview of alkene ozonolysis (traditional) 
<smiles>C=C(C)C1CCC(C)C(=O)C1</smiles>

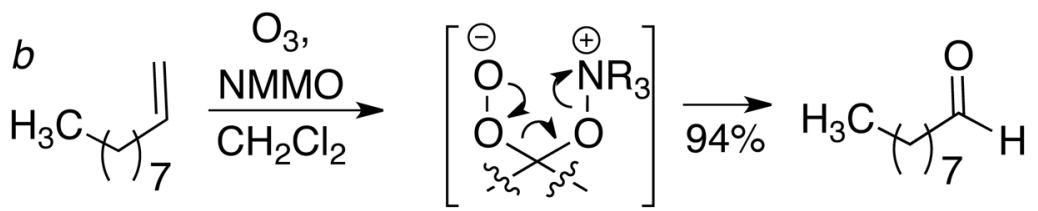

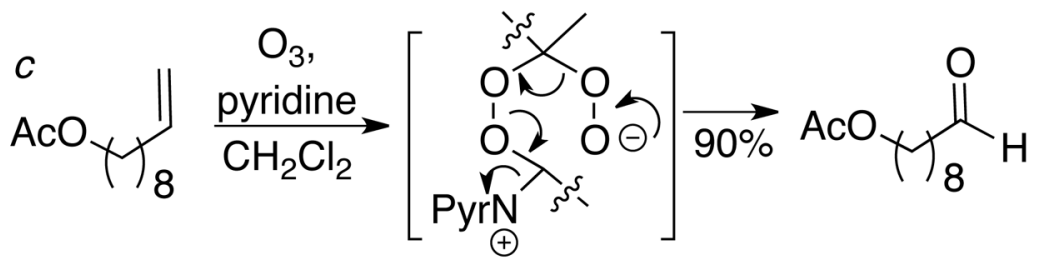

Scheme 2.

Overview of reductive ozonolyses 
Table 1

One-pot reductive ozonolysis and Horner- Emmons reaction

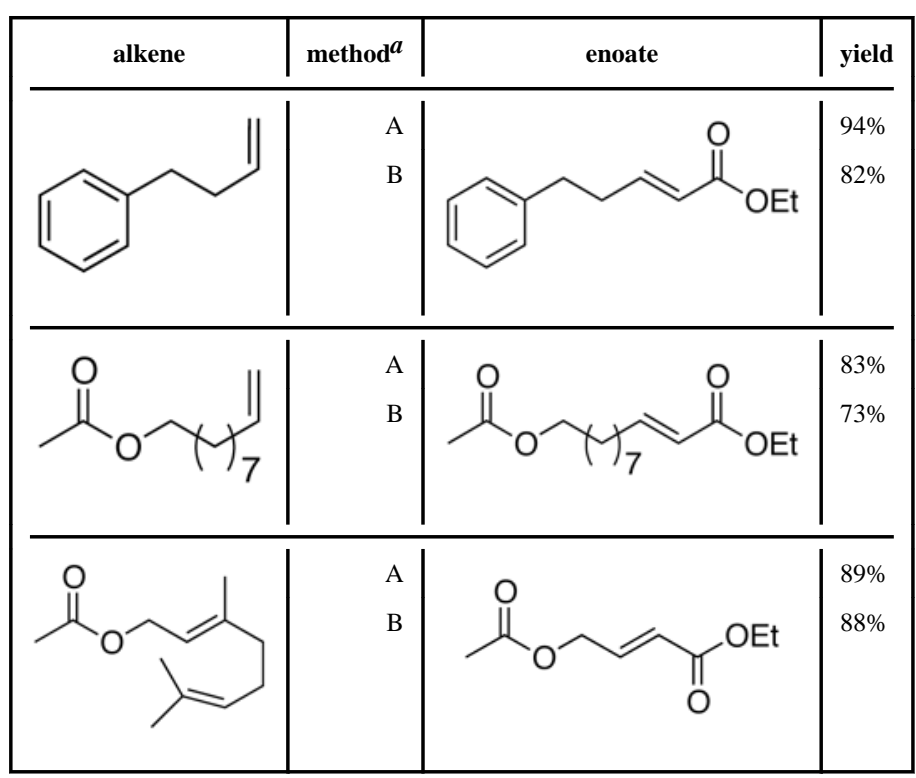

${ }^{a}$ (A) $\mathrm{O}_{3}$, NMMO ( 3 equiv), $\mathrm{CH}_{2} \mathrm{Cl}_{2}, 0{ }^{\circ} \mathrm{C}$; then Wittig ylide (1.1 equiv) in THF. B) $\mathrm{O}_{3}$, pyridine ( 3 equiv), $\mathrm{CH}_{2} \mathrm{Cl}_{2},-78{ }^{\circ} \mathrm{C}$; then Wittig ylide. 
Table 2

One-pot ozonolysis and Wittig olefination

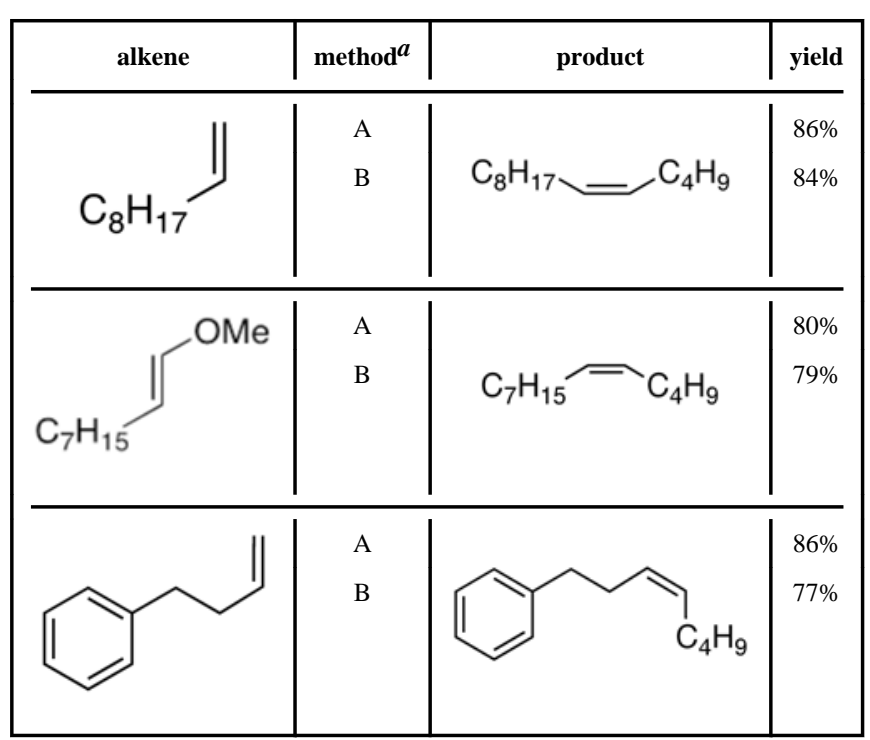

${ }^{a}$ (A) $\mathrm{O}_{3}, \mathrm{NMMO}$ ( 3 equiv), $\mathrm{CH}_{2} \mathrm{Cl}_{2}, 0^{\circ} \mathrm{C}$; then Wittig ylide (1.1 equiv) in THF. B) $\mathrm{O}_{3}$, pyridine ( 3 equiv), $\mathrm{CH}_{2} \mathrm{Cl}_{2},-78{ }^{\circ} \mathrm{C}$; then Wittig ylide. 
Table 3

One-pot ozonolysis and organometallic addition

\begin{tabular}{|c|c|c|c|c|c|c|c|}
\hline alkene & method $^{a}$ & $\mathbf{R}$ & product & yield \\
\hline & & $\mathrm{A}$ & $\mathrm{Ph}$ & & \\
\hline
\end{tabular}

${ }^{a}$ (A) $\mathrm{O}_{3}, \mathrm{NMMO}, \mathrm{CH}_{2} \mathrm{Cl}_{2}, 0^{\circ} \mathrm{C}$; add $\mathrm{RMgX}$ in ether. (B) $\mathrm{O}_{3}$, pyridine, $\mathrm{CH}_{2} \mathrm{Cl}_{2}, 0^{\circ} \mathrm{C}$; then $\mathrm{RMgX}$. 
Table 4

One-pot ozonolysis and Aldol reaction

\begin{tabular}{|l|l|l|l|l|}
\hline alkene & method $^{a}$ & product & yield \\
\hline & & & & \\
\hline
\end{tabular}

${ }^{a}$ (A) $\mathrm{O}_{3}, \mathrm{NMMO}, \mathrm{CH}_{2} \mathrm{Cl}_{2}, 0{ }^{\circ} \mathrm{C}$; lithium enolate of cyclohexanone; (B) same except $\mathrm{O}_{3}$, pyridine, $\mathrm{CH}_{2} \mathrm{Cl}_{2}, 0^{\circ} \mathrm{C}$. 
Table 5

One-pot ozonolysis and Lewis acid-mediated allylation

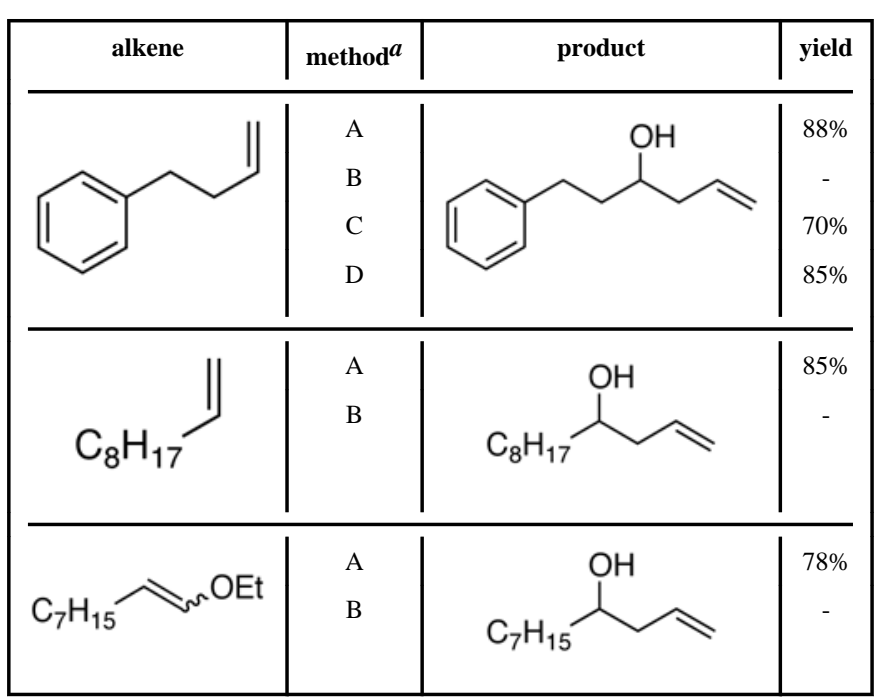

${ }^{a}$ (A) $\mathrm{O}_{3}, \mathrm{NMMO}, \mathrm{CH}_{2} \mathrm{Cl}_{2}, 0^{\circ} \mathrm{C}$; then $\mathrm{TiCl}_{4}$, allylSiMe3. (B) same, but $\mathrm{O}_{3}$, pyridine, $\mathrm{CH}_{2} \mathrm{Cl}_{2},-78{ }^{\circ} \mathrm{C}$; (C) $\mathrm{O}_{3}$, pyridine, $\mathrm{CH}_{2} \mathrm{Cl}_{2},-78{ }^{\circ} \mathrm{C}$; then $\mathrm{BF}_{3} \cdot \mathrm{OEt} 2$, allylSiMe3. D) Same except $\mathrm{O}_{3}, \mathrm{NMMO}, \mathrm{CH}_{2} \mathrm{Cl}_{2}, 0^{\circ} \mathrm{C}$. 
Supporting Information

\title{
Tandem application of $\mathrm{C}-\mathrm{C}$ bond-forming reactions with reductive ozonolysis
} (22 pages)

\author{
Rachel Willand-Charnley and Patrick H. Dussault* \\ Department of Chemistry, University of Nebraska-Lincoln \\ Lincoln NE 68588-0304, USA; e-mail: pdussault1@unl.edu.
}

(E)-Ethyl 5-phenylpent-2-enoate $\left({ }^{1} \mathrm{H}\right.$ NMR)

(E)-Ethyl-11-acetoxy-2-undecenoate $\left({ }^{1} \mathrm{H},{ }^{13} \mathrm{C}\right.$ NMR; IR)

$3-5$

(E)-Ethyl 4-acetoxybut-2-enoate $\left({ }^{1} \mathrm{H}\right.$ NMR)

(Z)-Tridec-5-ene ( ${ }^{1} \mathrm{H}$ NMR)

(Z)-Tetradec-5-ene ( ${ }^{1} \mathrm{H}$ NMR)

(Z)-Oct-3-en-1-ylbenzene $\left({ }^{1} \mathrm{H}\right.$ NMR)

2-(1-Hydroxy-3-phenylpropyl)cyclohexanone $\left({ }^{1} \mathrm{H}\right.$ NMR $) \quad 10$

2-(1-Hydroxynonyl)cyclohexanone $\left({ }^{1} \mathrm{H}\right.$ NMR)

2-(1-Hydroxyoctyl)cyclohexanone ( ${ }^{1} \mathrm{H}$ NMR)

1-Phenyldecan-1-ol ( ${ }^{1} \mathrm{H}$ NMR)

Decan-2-ol ( ${ }^{1} \mathrm{H}$ NMR)

2-Phenylnopinol ( ${ }^{1} \mathrm{H}$ NMR)

4-(tert-Butyl)-1-methylcyclohexanol ( ${ }^{1} \mathrm{H}$ NMR)

1,3-Diphenylpropan-1-ol ( ${ }^{1} \mathrm{H}$ NMR)

1-Phenyloctan-1-ol ( ${ }^{1} \mathrm{H}$ NMR)

1-Phenylhex-5-en-3-ol ( ${ }^{1} \mathrm{H}$ NMR)

Dodec-1-en-4-ol ( ${ }^{1} \mathrm{H}$ NMR)

Undec-1-en-4-ol ( ${ }^{1} \mathrm{H}$ NMR)

Ethyl-7-oxooct-2-enoate ( ${ }^{1} \mathrm{H}$ NMR) 
Supporting Information: Willand-Charnley and Dussault "Tandem application of C-C bondforming reactions with reductive ozonolysis"

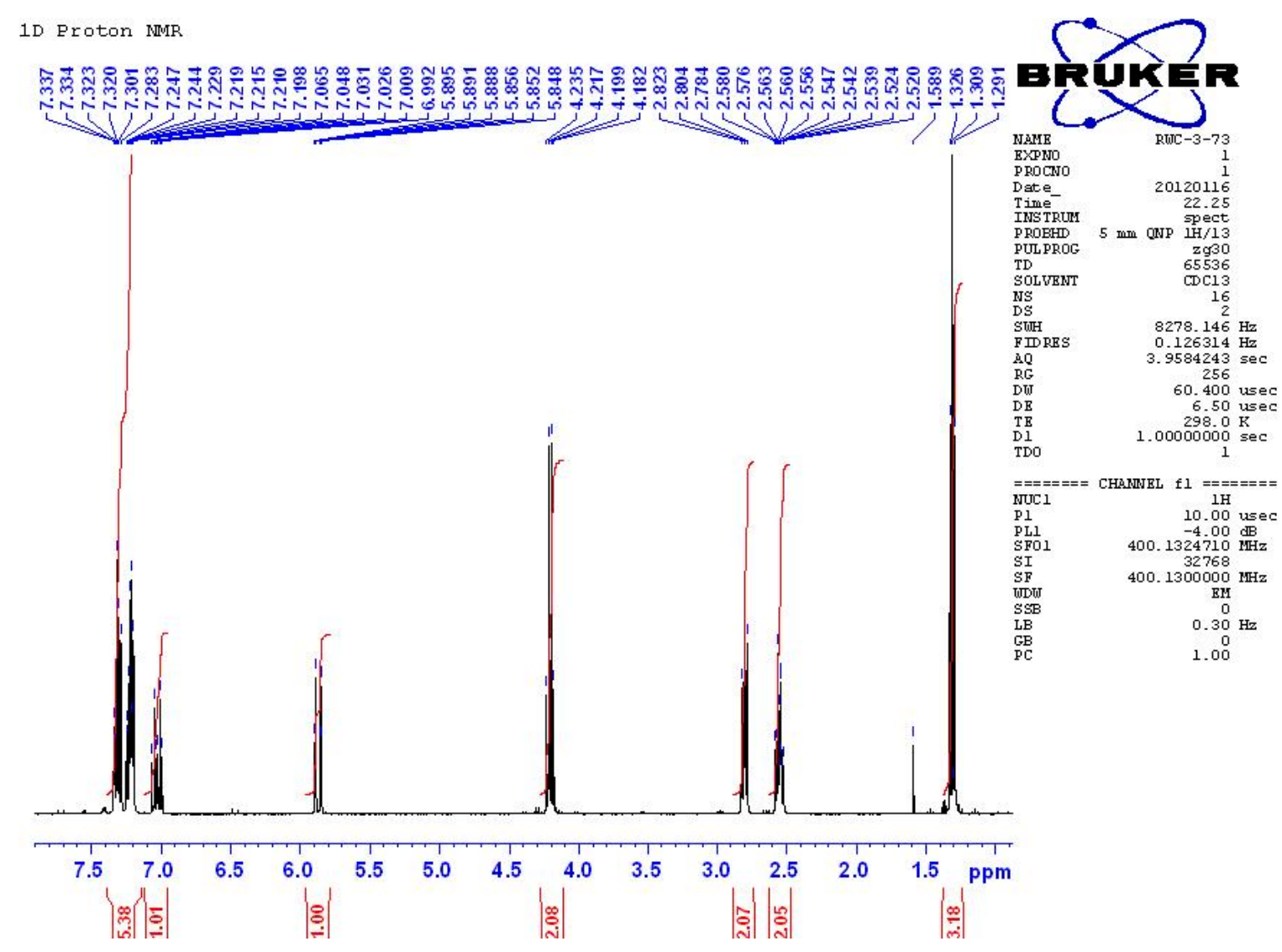<smiles>CCOC(=O)/C=C/CCc1ccccc1</smiles>

(E)-ethyl 5-phenylpent-2-enoate 
Supporting Information: Willand-Charnley and Dussault "Tandem application of C-C bondforming reactions with reductive ozonolysis"<smiles>CCOC(=O)/C=C/CCCCCCCCOC(C)=O</smiles>

(E)-ethyl 11-acetoxyundec-2-enoate

1D Proton

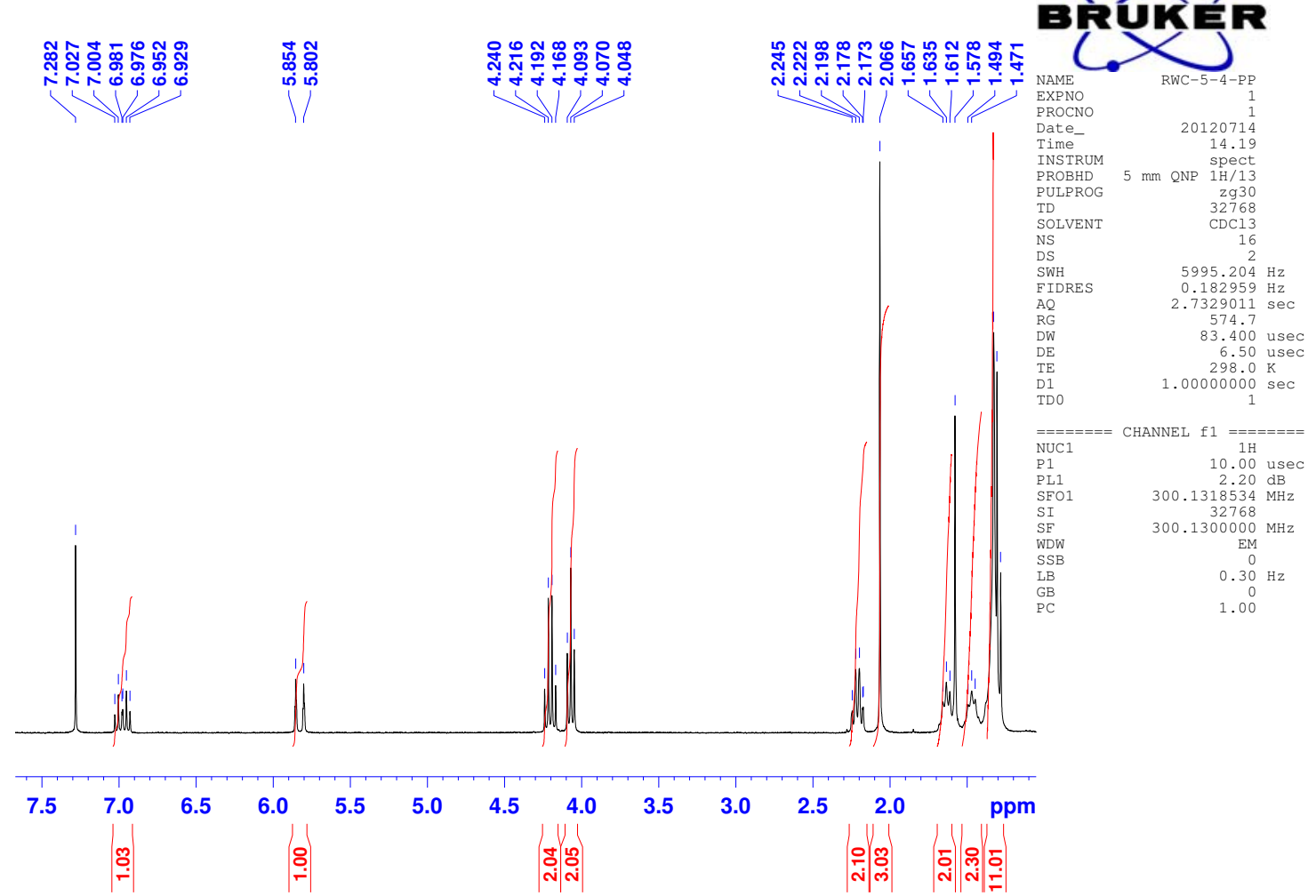


Supporting Information: Willand-Charnley and Dussault "Tandem application of C-C bondforming reactions with reductive ozonolysis"<smiles>CCOC(=O)/C=C/CCCCCCCCOC(C)=O</smiles>

(E)-ethyl 11-acetoxyundec-2-enoate

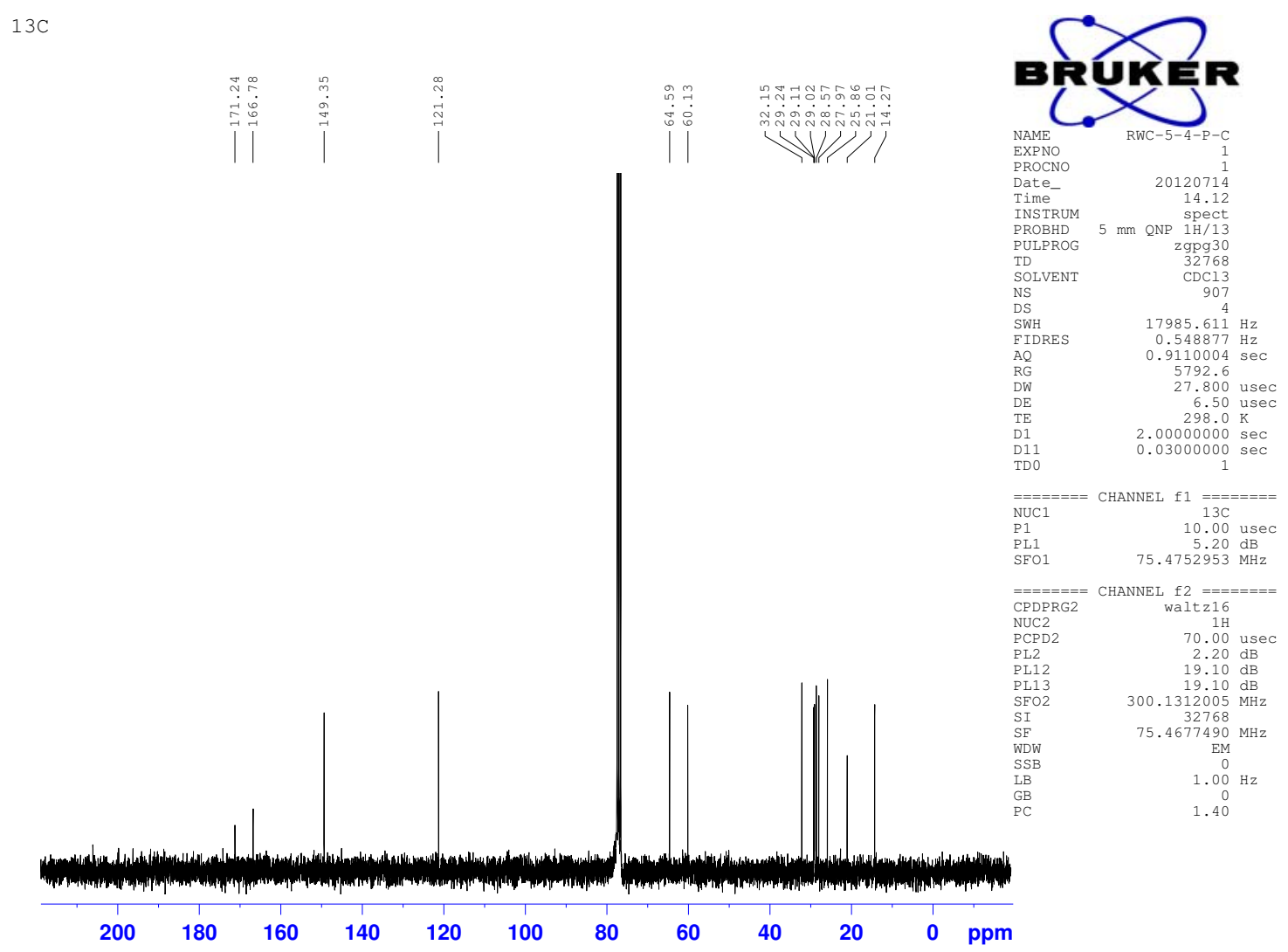


Supporting Information: Willand-Charnley and Dussault "Tandem application of C-C bondforming reactions with reductive ozonolysis"<smiles>CCOC(=O)/C=C/CCCCCCCCOC(C)=O</smiles>

(E)-ethyl 11-acetoxyundec-2-enoate

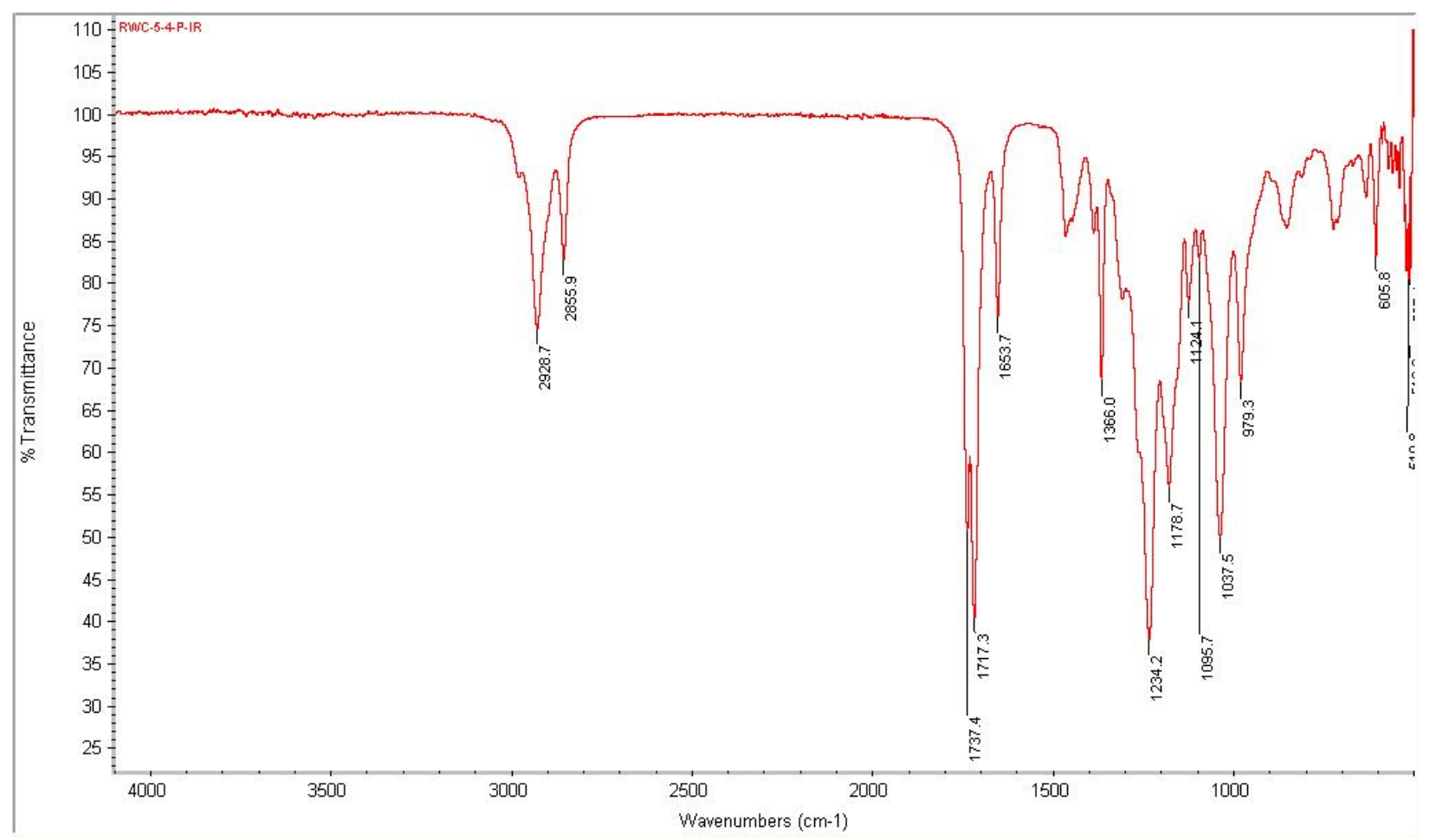


Supporting Information: Willand-Charnley and Dussault "Tandem application of C-C bondforming reactions with reductive ozonolysis"

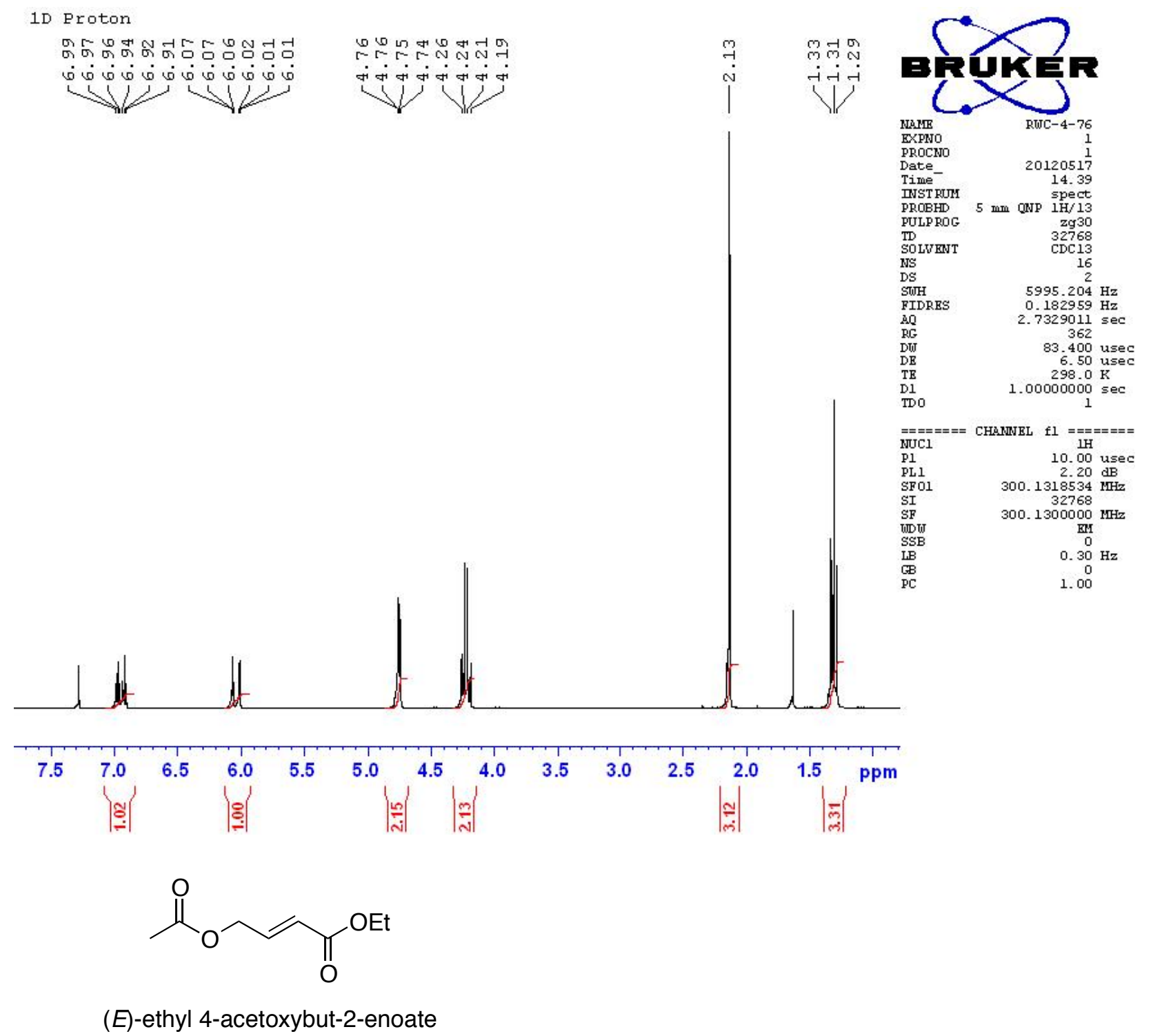


Supporting Information: Willand-Charnley and Dussault "Tandem application of C-C bondforming reactions with reductive ozonolysis"
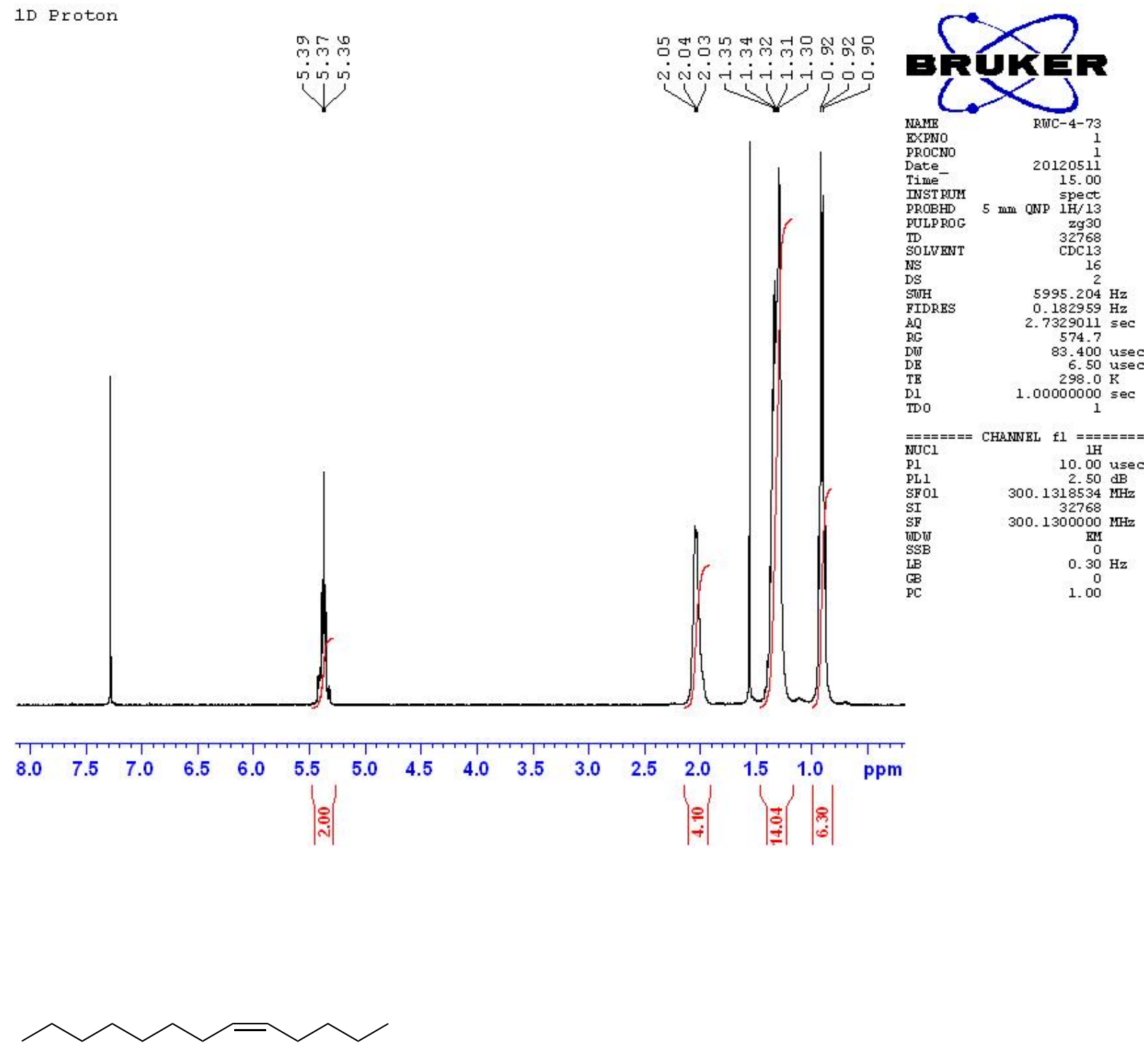

(Z)-tridec-5-ene 
Supporting Information: Willand-Charnley and Dussault "Tandem application of C-C bondforming reactions with reductive ozonolysis"

1D Proton

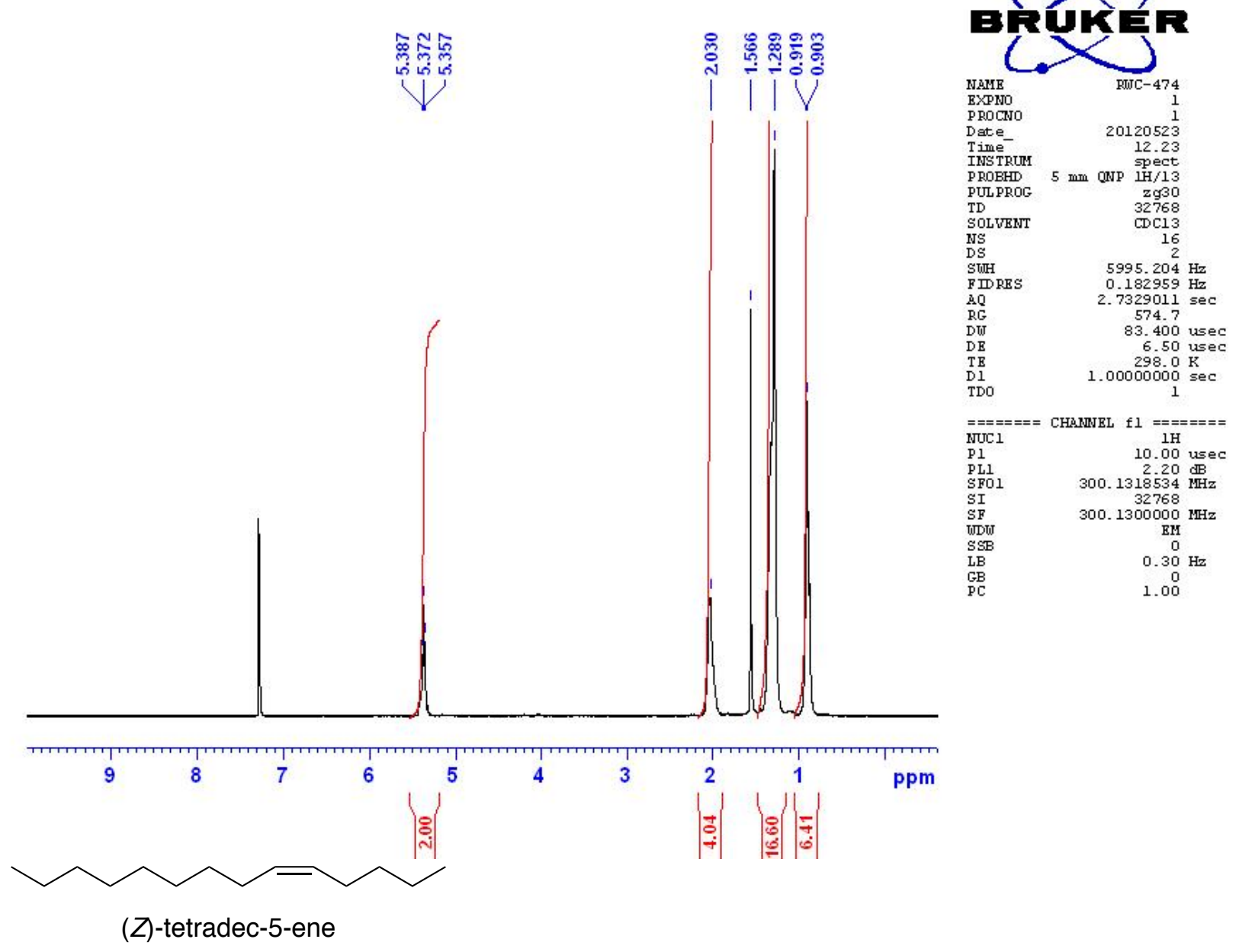


Supporting Information: Willand-Charnley and Dussault "Tandem application of C-C bondforming reactions with reductive ozonolysis"
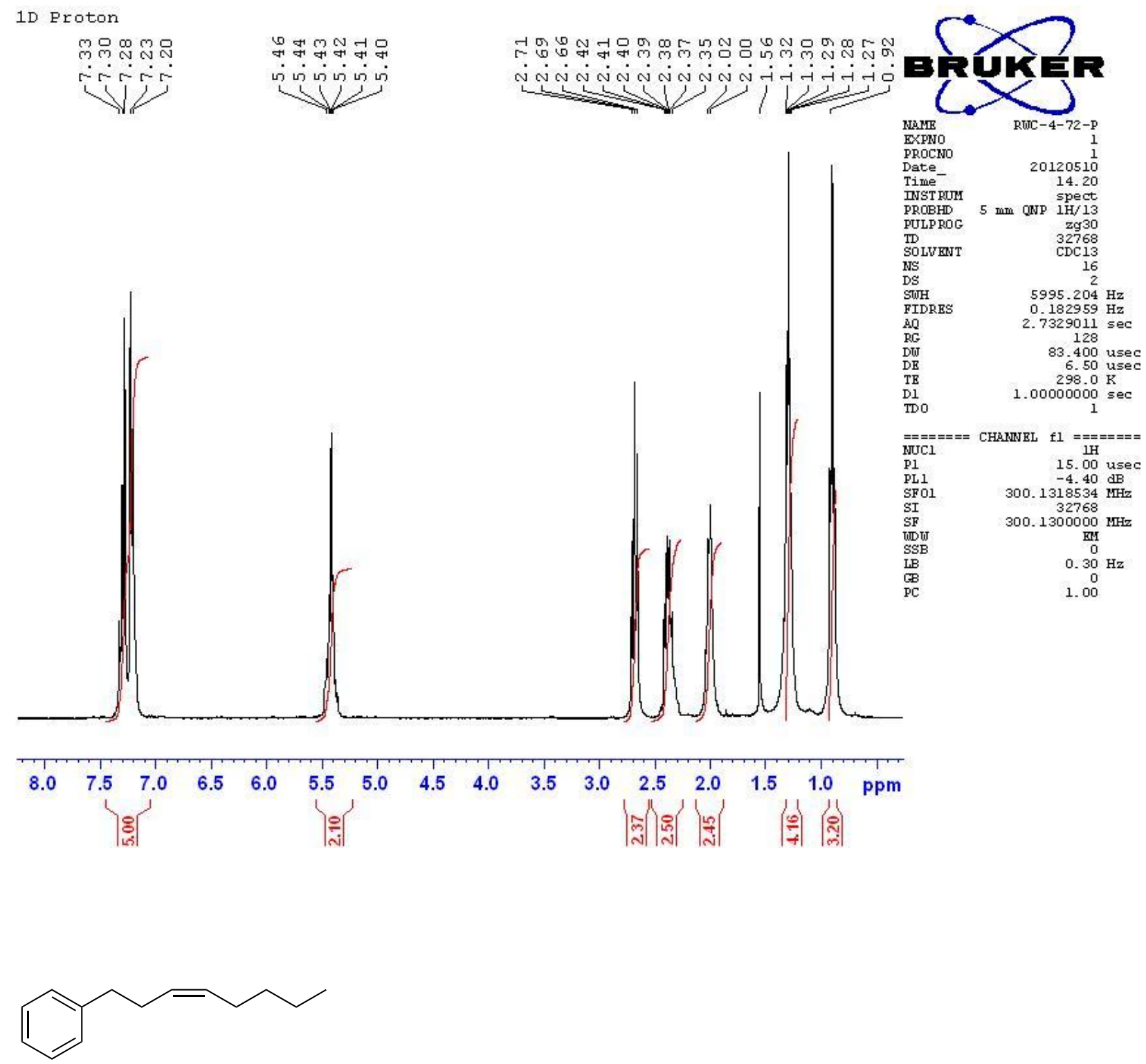

(Z)-oct-3-en-1-ylbenzene 
Supporting Information: Willand-Charnley and Dussault "Tandem application of C-C bondforming reactions with reductive ozonolysis"

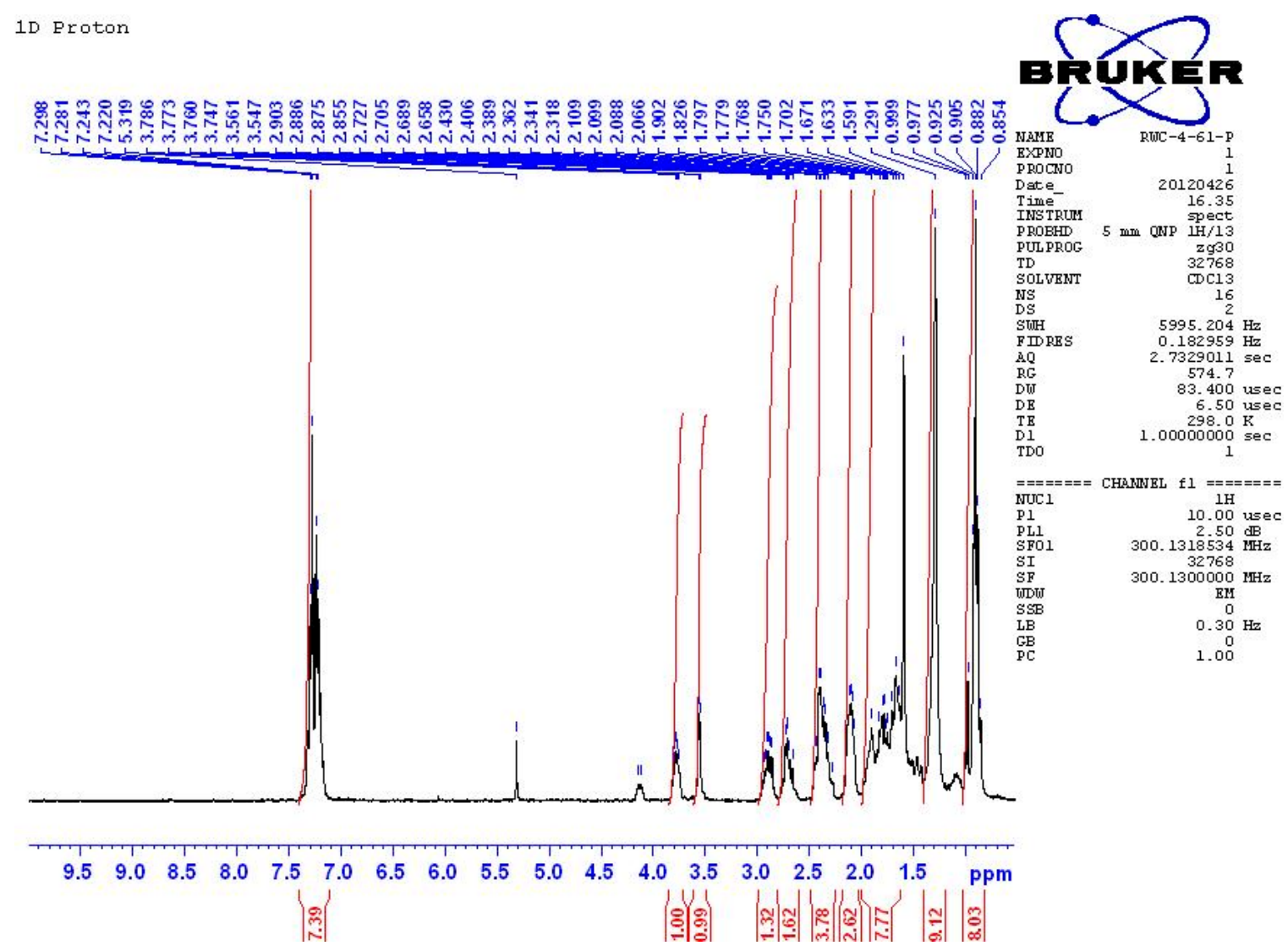<smiles>O=C1CCCCC1C(O)CCc1ccccc1</smiles>

\section{2-(1-hydroxy-3-phenylpropyl)cyclohexanone}


Supporting Information: Willand-Charnley and Dussault "Tandem application of C-C bondforming reactions with reductive ozonolysis"

1D Proton MMR
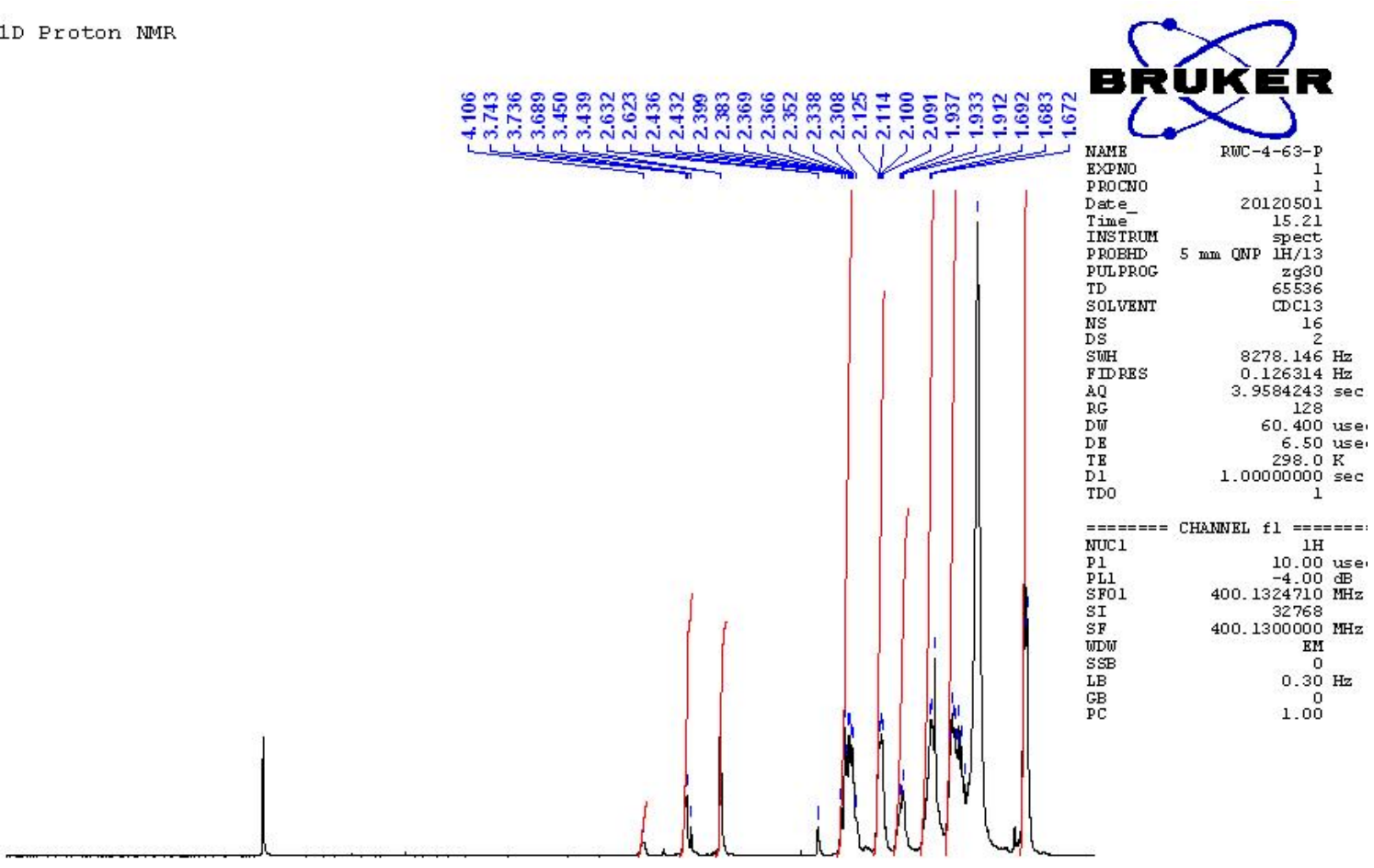

$\begin{array}{llllllllllllllllll}9.0 & 8.5 & 8.0 & 7.5 & 7.0 & 6.5 & 6.0 & 5.5 & 5.0 & 4.5 & 4.0 & 3.5 & 3.0 & 2.5 & 2.0 & 1.5 & 1.0 & \text { ppm }\end{array}$

|ิ

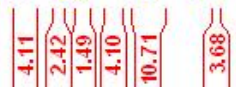<smiles>CCCCCCCCC(O)C1CCCCC1=O</smiles>

\section{2-(1-hydroxynonyl)cyclohexanone}


Supporting Information: Willand-Charnley and Dussault "Tandem application of C-C bondforming reactions with reductive ozonolysis"

1D Proton
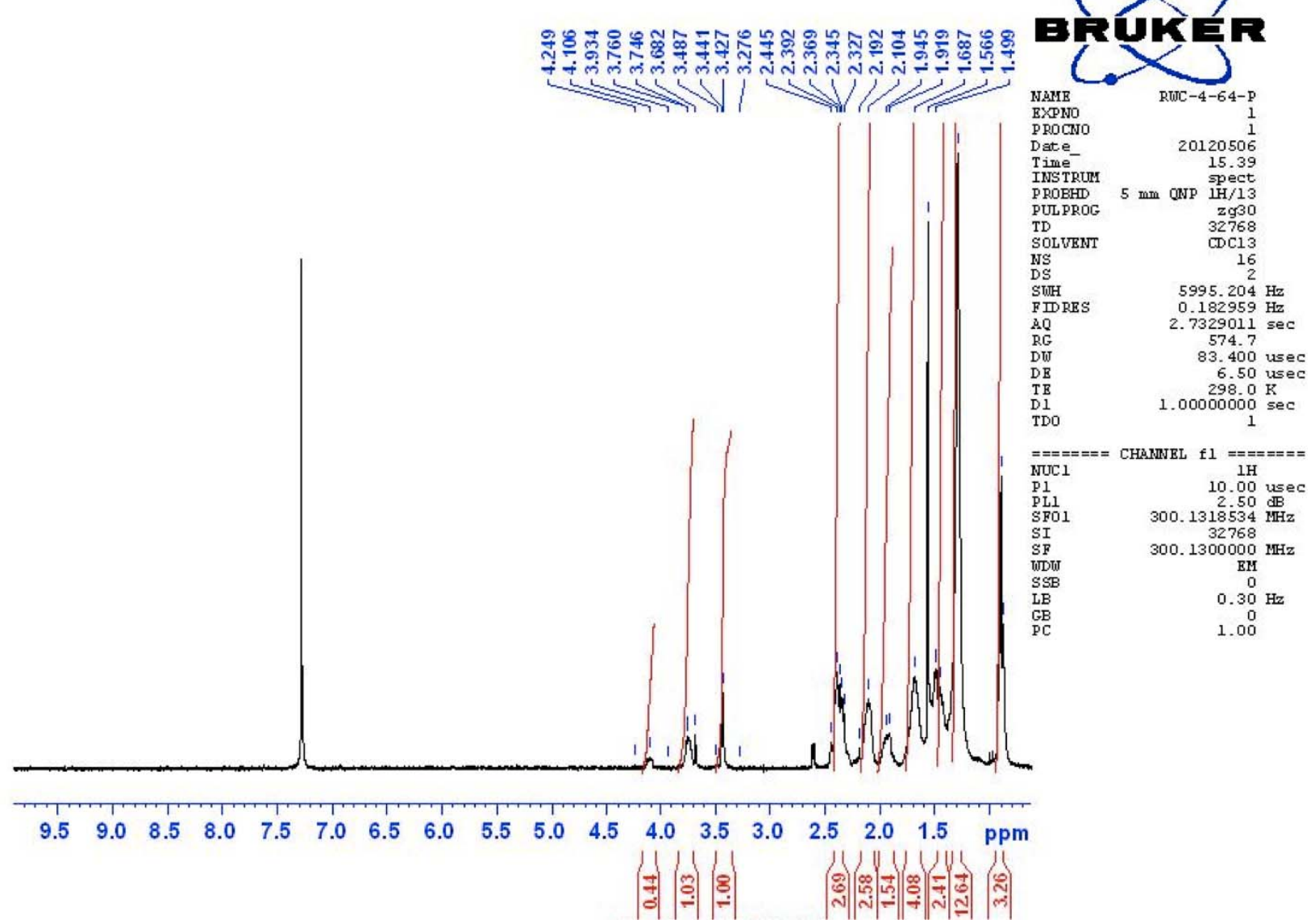<smiles>CCCCCCCC(O)C1CCCCC1=O</smiles>

2-(1-hydroxyoctyl)cyclohexanone 
Supporting Information: Willand-Charnley and Dussault "Tandem application of C-C bondforming reactions with reductive ozonolysis"
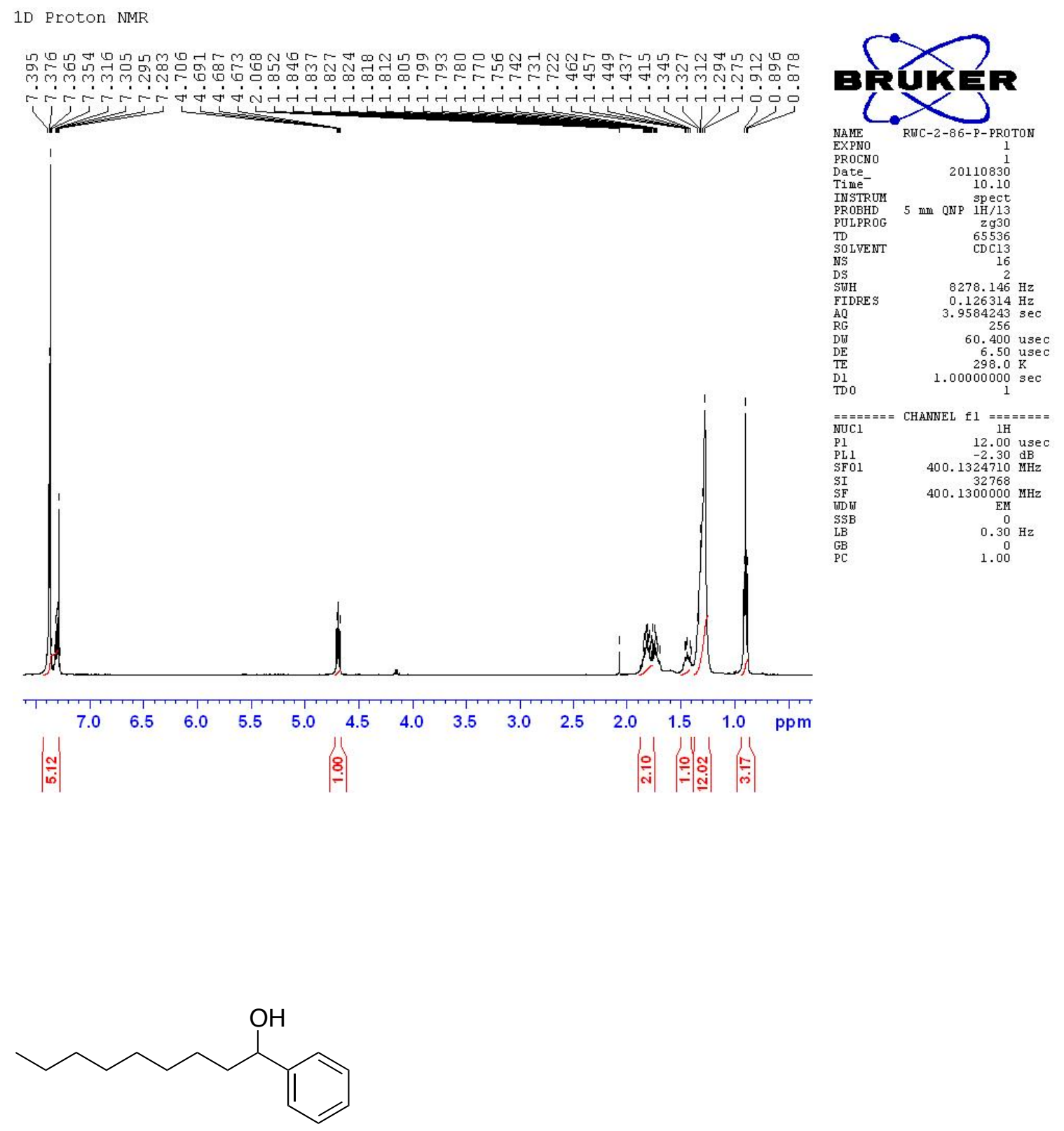

1-phenylnonan-1-ol 
Supporting Information: Willand-Charnley and Dussault "Tandem application of C-C bondforming reactions with reductive ozonolysis"
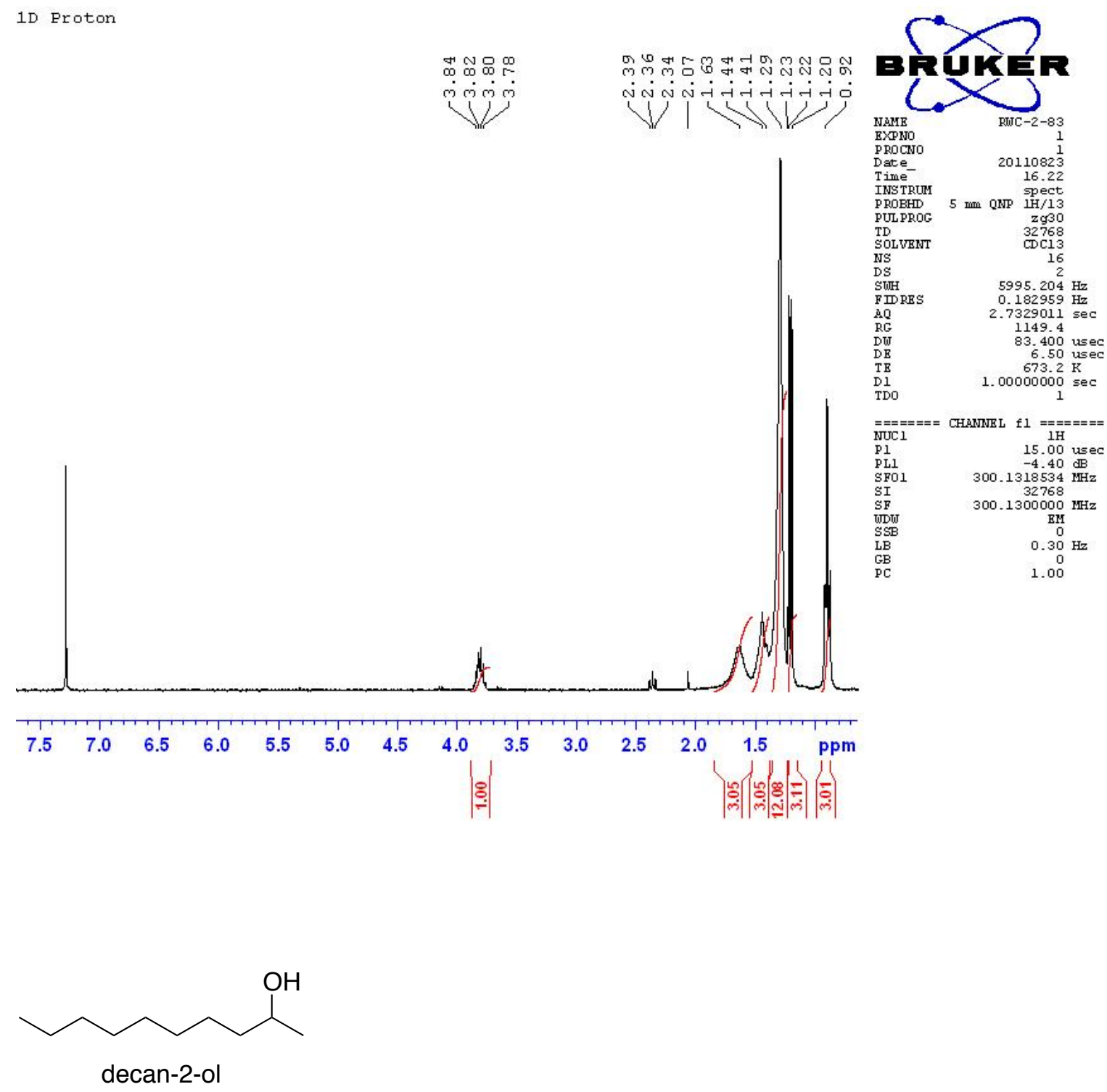
Supporting Information: Willand-Charnley and Dussault "Tandem application of C-C bondforming reactions with reductive ozonolysis"

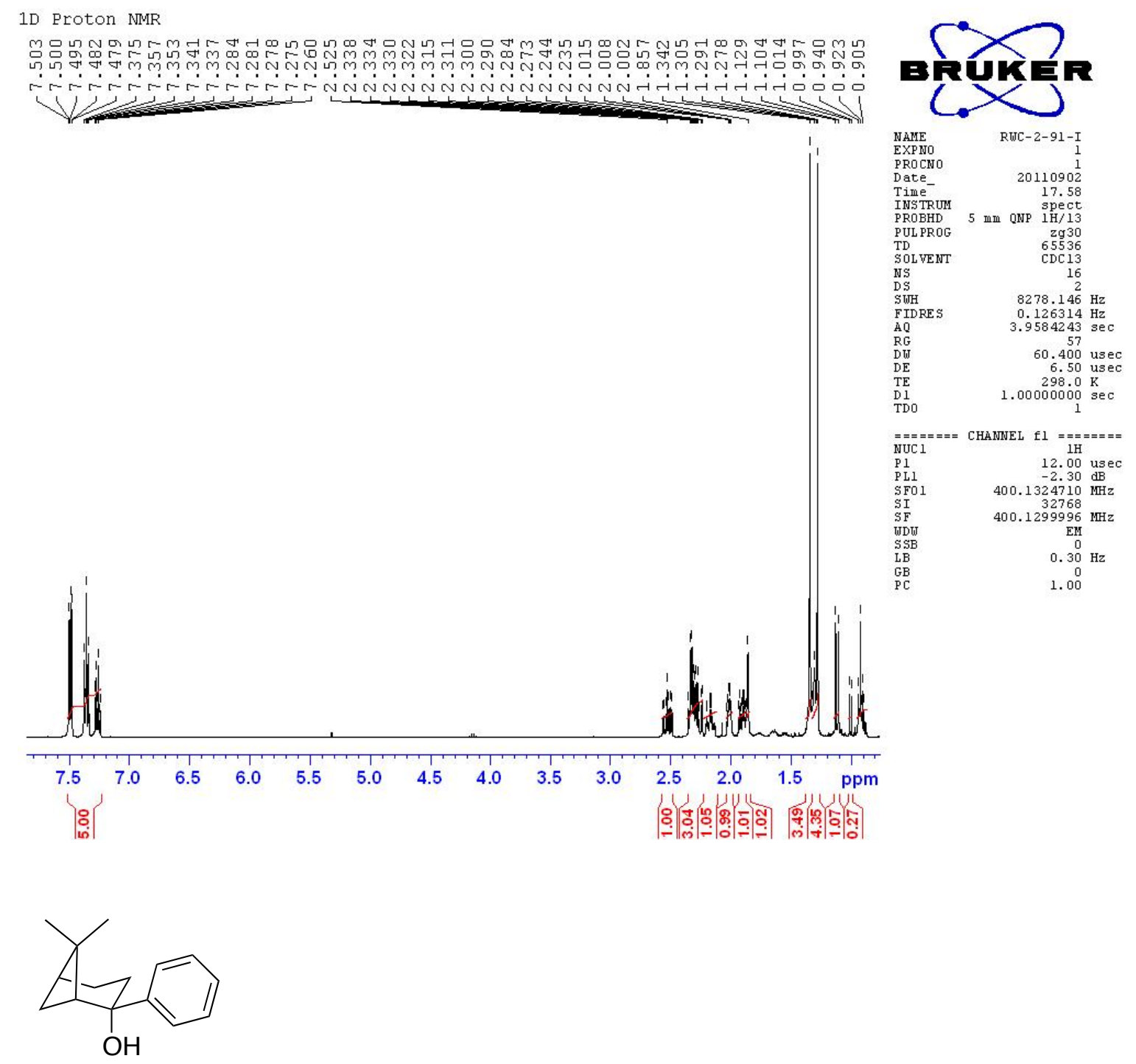

\section{2-Phenylnopinol}


Supporting Information: Willand-Charnley and Dussault "Tandem application of C-C bondforming reactions with reductive ozonolysis"
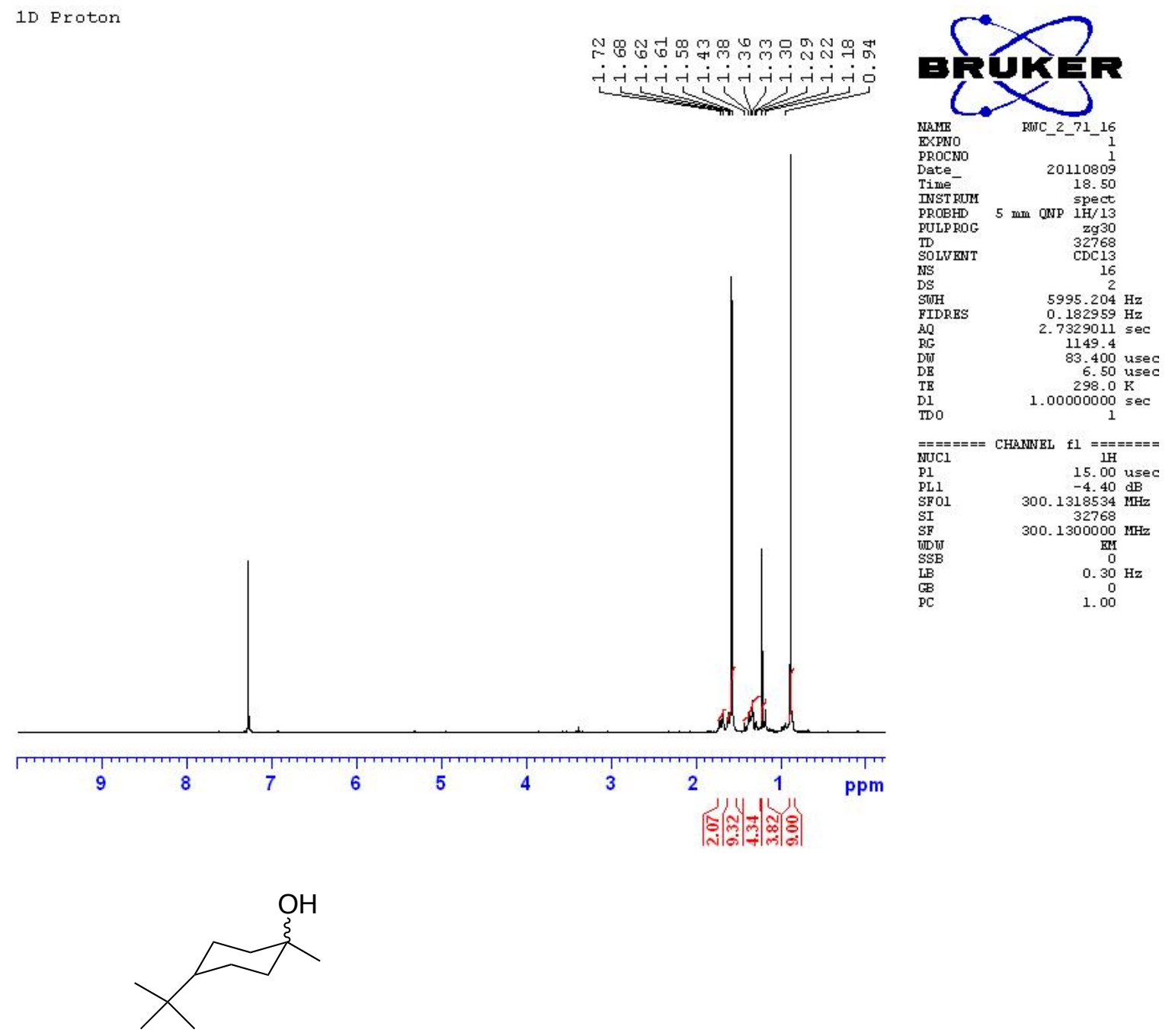

4-(tert-butyl)-1-methylcyclohexanol 
Supporting Information: Willand-Charnley and Dussault "Tandem application of C-C bondforming reactions with reductive ozonolysis"

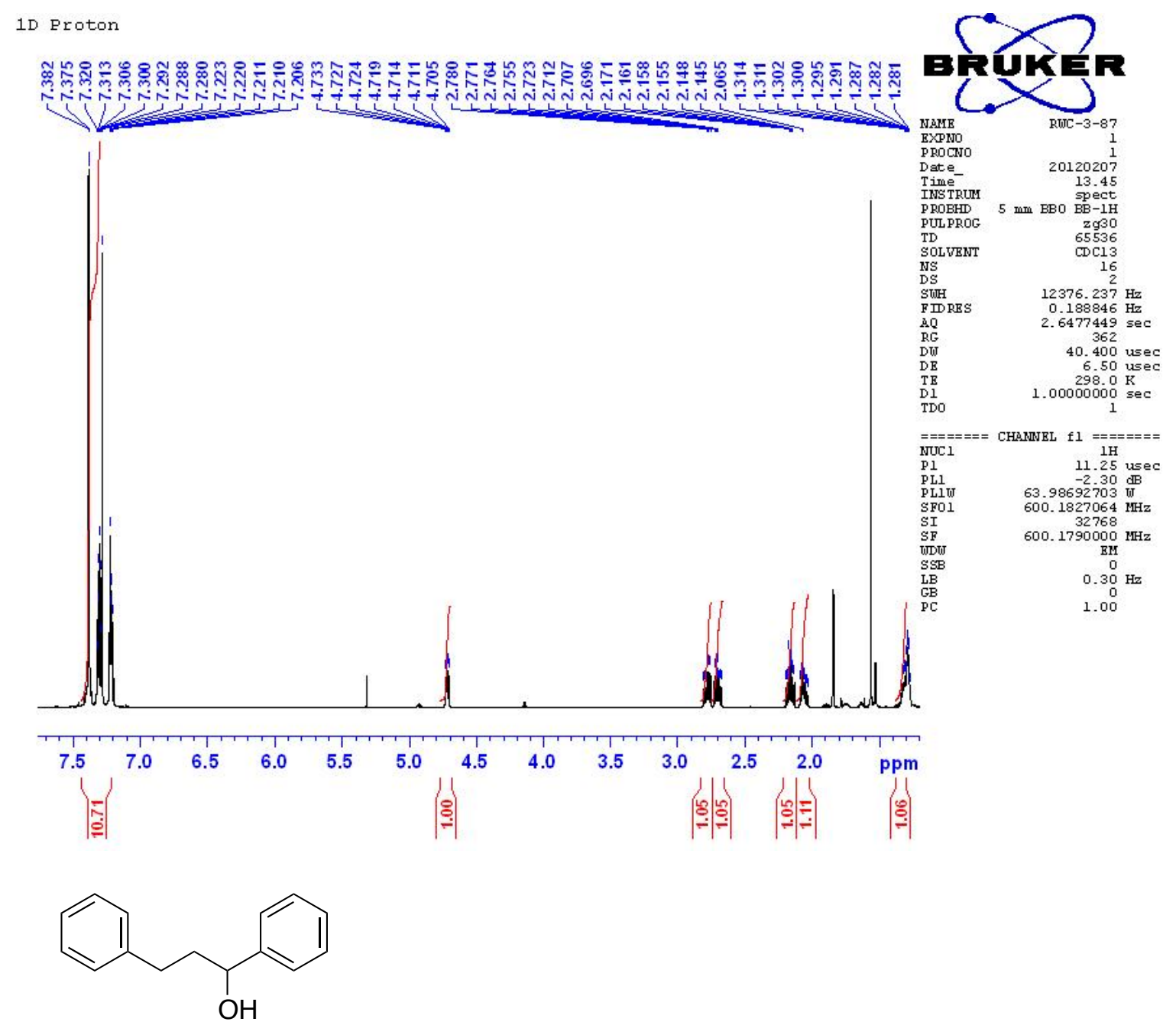

\section{1,3-diphenylpropan-1-ol}


Supporting Information: Willand-Charnley and Dussault "Tandem application of C-C bondforming reactions with reductive ozonolysis"

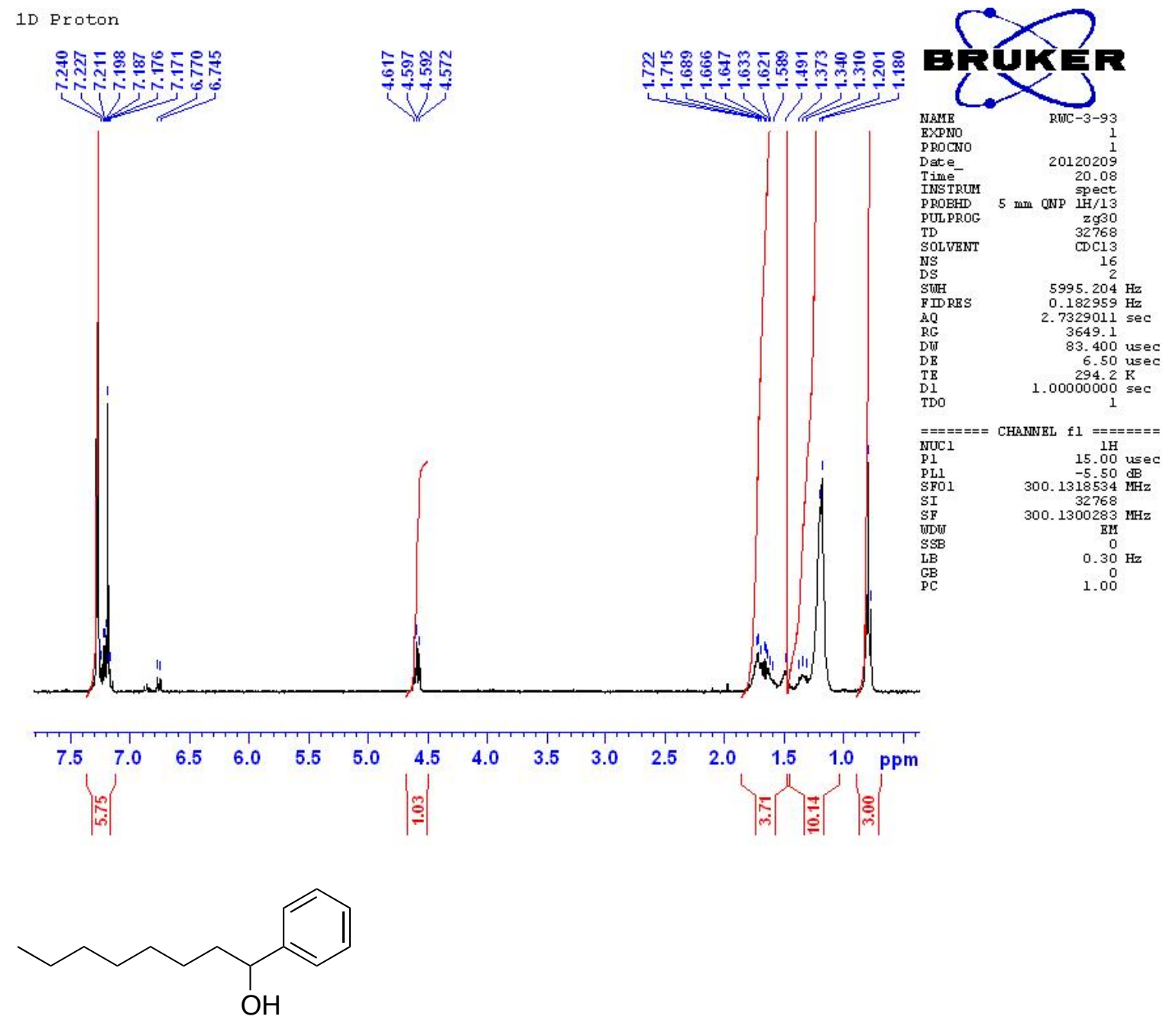

\section{. 1-phenyloctan-1-ol}


Supporting Information: Willand-Charnley and Dussault "Tandem application of C-C bondforming reactions with reductive ozonolysis"

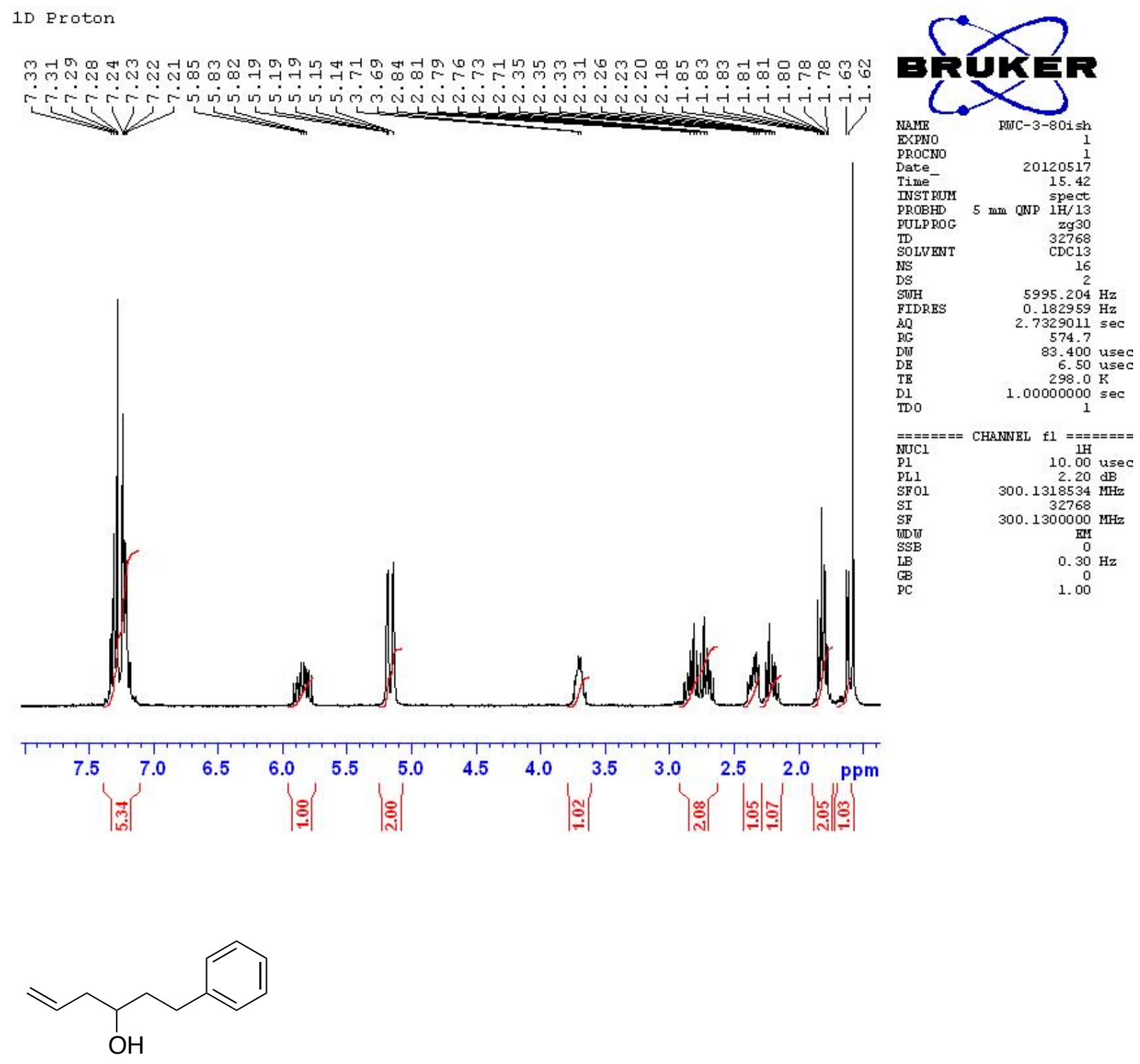

\section{1-phenylhex-5-en-3-ol}


Supporting Information: Willand-Charnley and Dussault "Tandem application of C-C bondforming reactions with reductive ozonolysis"
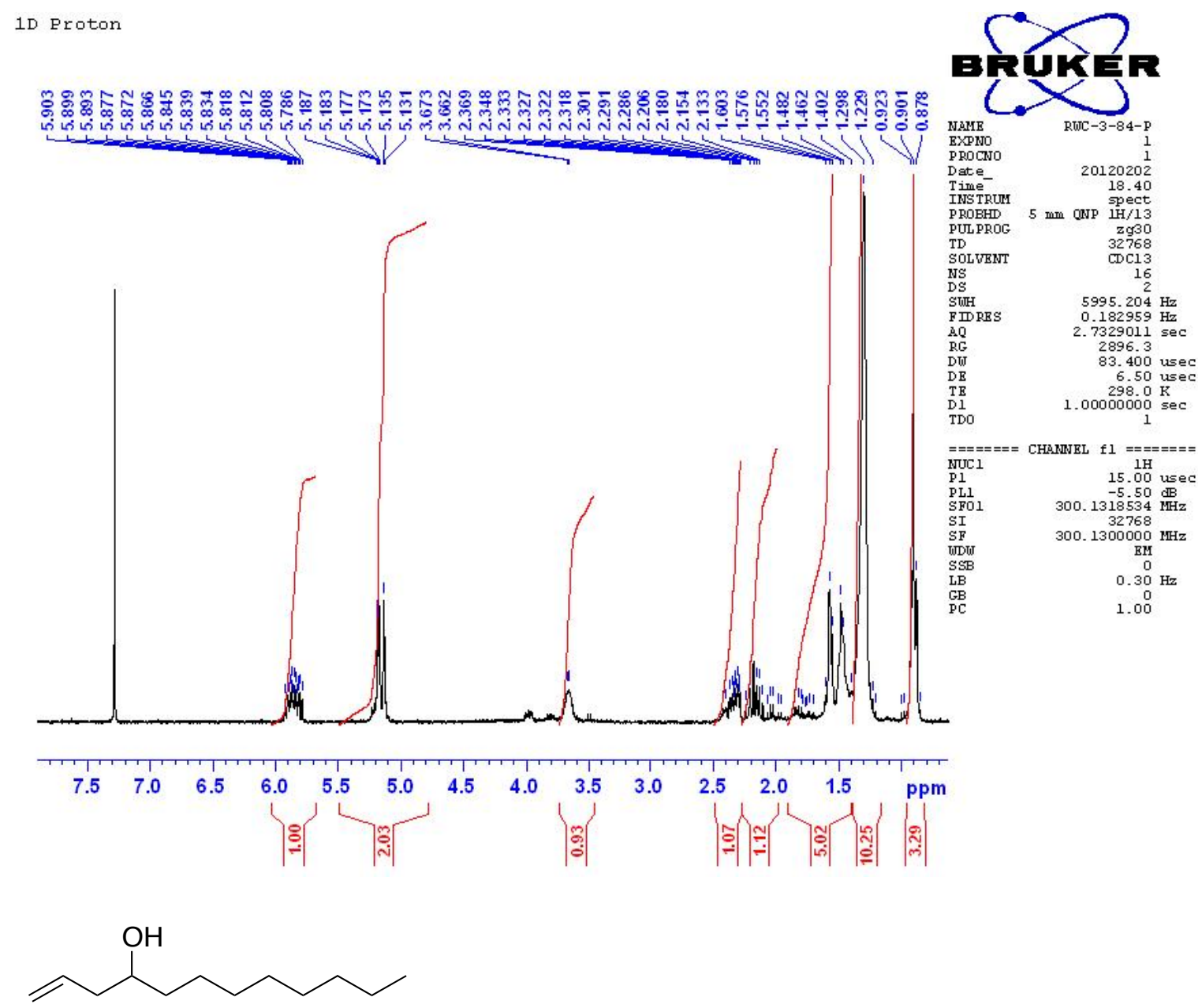

Dodec-1-en-4-ol 
Supporting Information: Willand-Charnley and Dussault "Tandem application of C-C bondforming reactions with reductive ozonolysis"

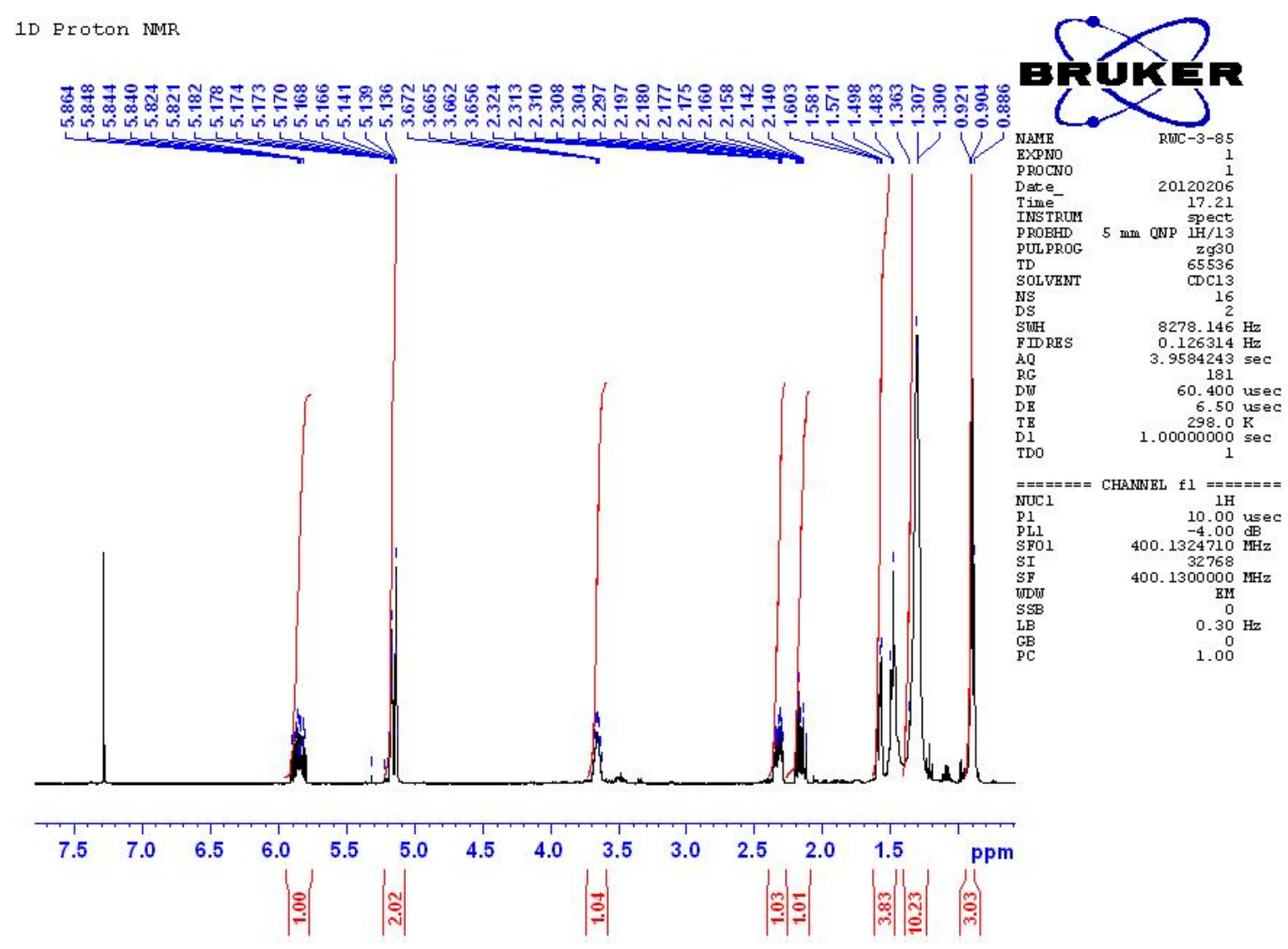<smiles>C=CCC(O)CCCCCCC</smiles>

Undec-1-en-4-ol 
Supporting Information: Willand-Charnley and Dussault "Tandem application of C-C bondforming reactions with reductive ozonolysis"

1D Proton NMR

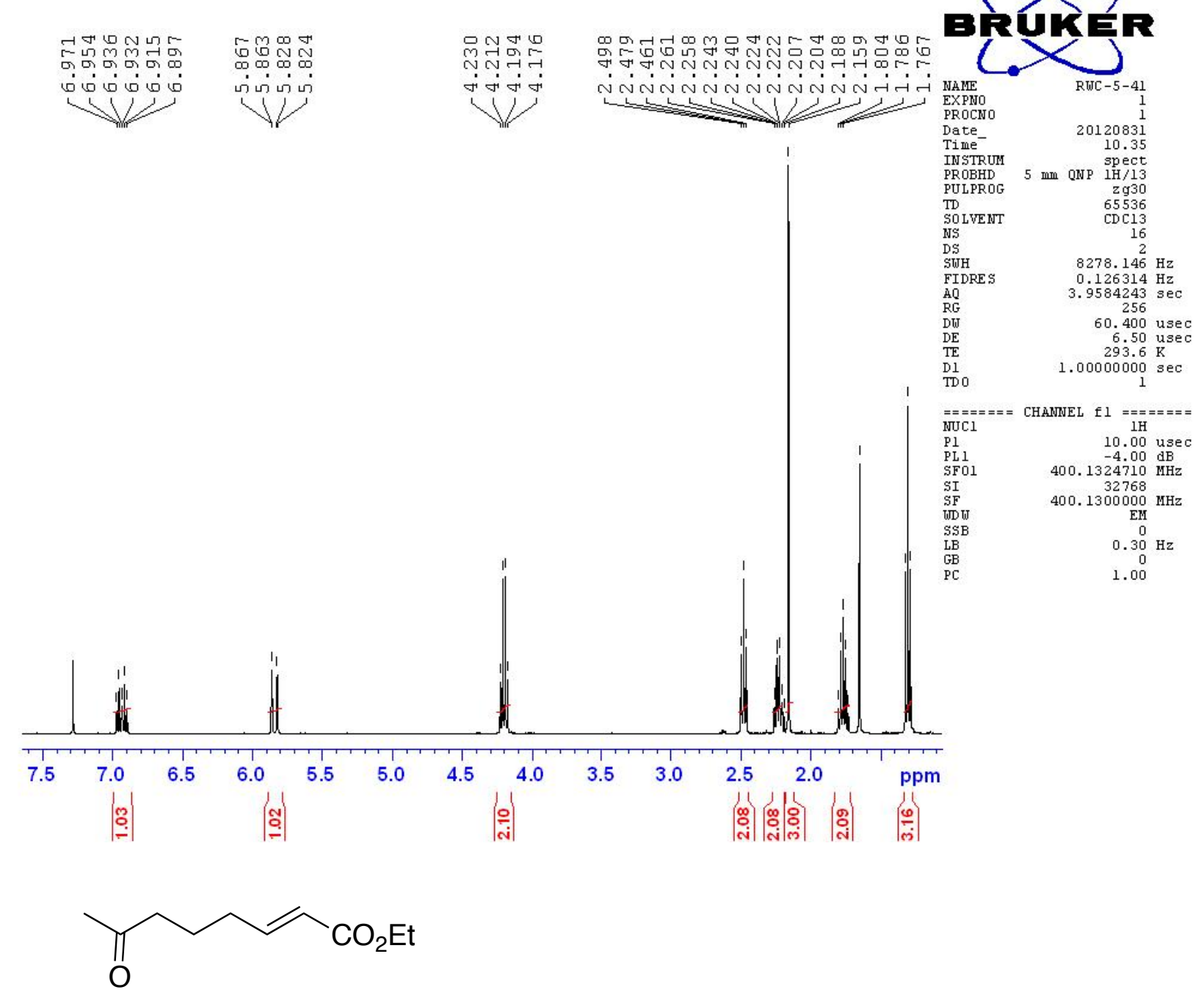

Ethyl 7-oxo-2-octenoate 